NBER WORKING PAPER SERIES

\title{
FEAR OF FRACKING? THE IMPACT OF THE SHALE GAS EXPLORATION ON HOUSE PRICES IN BRITAIN
}

\author{
Steve Gibbons \\ Stephan Heblich \\ Esther Lho \\ Christopher Timmins \\ Working Paper 22859 \\ http://www.nber.org/papers/w22859 \\ NATIONAL BUREAU OF ECONOMIC RESEARCH \\ 1050 Massachusetts Avenue \\ Cambridge, MA 02138 \\ November 2016
}

We thank Lin Fan for excellent research assistance and seminar participants at the University of Amsterdam, the University of Bristol, and the annual SERC meeting for useful comments. This work was part-funded by the Economic and Social Research Council (ESRC) through the Applied Quantitative Methods Network: Phase II, grant number ES/K006460/1 and the Centre for Economic Performance, grant number ES/M010341/1. The views expressed herein are those of the authors and do not necessarily reflect the views of the National Bureau of Economic Research.

NBER working papers are circulated for discussion and comment purposes. They have not been peer-reviewed or been subject to the review by the NBER Board of Directors that accompanies official NBER publications.

(C) 2016 by Steve Gibbons, Stephan Heblich, Esther Lho, and Christopher Timmins. All rights reserved. Short sections of text, not to exceed two paragraphs, may be quoted without explicit permission provided that full credit, including $\left({ }^{\circ}\right.$ notice, is given to the source. 
Fear of Fracking? The Impact of the Shale Gas Exploration on House Prices in Britain Steve Gibbons, Stephan Heblich, Esther Lho, and Christopher Timmins

NBER Working Paper No. 22859

November 2016

JEL No. Q42,Q5,Q51

\begin{tabular}{|c|c|}
\hline \multicolumn{2}{|c|}{$\underline{\text { ABSTRACT }}$} \\
\hline \multicolumn{2}{|c|}{$\begin{array}{l}\text { Shale gas has grown to become a major new source of energy in countries around the globe. } \\
\text { While its importance for energy supply is well recognized, there has also been public concern } \\
\text { over potential risks such as damage to buildings and contamination of water supplies caused by } \\
\text { geological disturbance from the hydraulic fracturing ('fracking') extraction process. Although } \\
\text { commercial development has not yet taken place in the UK, licenses for drilling were issued in } \\
2008 \text { implying potential future development. This paper examines whether public fears about } \\
\text { fracking are evident in changes in house prices in areas that have been licensed for shale gas } \\
\text { exploration. Our estimates suggest differentiated effects. Licensing did not affect house prices but } \\
\text { fracking the first well in } 2011 \text {, which caused two minor earthquakes, did. We find a } 2.7-4.1 \\
\text { percent house price decrease in the area where the earthquakes occurred. Robustness checks } \\
\text { confirm our findings. }\end{array}$} \\
\hline Steve Gibbons & Esther Lho \\
\hline Department of Geography and Environment & Department of Economics, Duke University \\
\hline London School of Economics & PO Box 90097 \\
\hline Houghton Street & Durham, NC 27708 \\
\hline London WC2A $2 \mathrm{AE}$ & el85@duke.edu \\
\hline $\mathrm{UK}$ & \\
\hline s.gibbons@1se.ac.uk & Christopher Timmins \\
\hline & Department of Economics \\
\hline Stephan Heblich & Duke University \\
\hline Department of Economics & 209 Social Sciences Building \\
\hline University of Bristol & P.O. Box 90097 \\
\hline 8 Woodland Road & Durham, NC 27708-0097 \\
\hline Bristol BS8 1TN & and NBER \\
\hline UK & christopher.timmins@duke.edu \\
\hline
\end{tabular}




\section{Introduction}

The advent of cost-reducing technological innovations associated with hydraulic fracturing and horizontal drilling has propelled shale gas to become one of the most promising and viable new global sources of energy. With the discovery of large reserves around the world, shale gas can support global energy needs for decades. The US Energy Information Administration estimated in 2012 that United States natural gas resources will last for up to 87 years and the British Department of Energy and Climate Change suggested in 2013 that Britain has enough shale gas deposits to supply the UK for about 25 years. In the US, a shale gas boom has boosted domestic energy supplies and the profits of producers (Feyrer et al., 2015). At the same time, shale gas development has raised concerns about externalities (i.e., environmental, disamenity, and other costs borne by nearby landowners and other stakeholders besides the drilling company). During the extraction process, large amounts of high-pressure water and additives are used to fracture the rock layer and release embedded shale gas. The water is transported by trucks, thus raising concerns about noise, road damage and accidents due to increased traffic (Gilman et al., 2013; Muehlenbachs and Krupnick, 2014). Increased air pollution may result from this truck traffic and from drilling operations (Colborn and Kwiatkowski, 2014; Caulton et al., 2014; Roy and Robinson, 2014). Moreover, there is a risk of soil or water contamination caused by metals, radioactive and saline wastewater, or by the added chemicals used to treat the wells (Olmstead et al., 2013; Warner et al., 2013; Fontenot et al., 2013). More recently, there have also been rising concerns about seismic activity induced by gas exploration (Koster and van Ommeren, 2015). In the US, these costs may be compensated to some degree, with many US households owning the rights to their underlying minerals and receiving offsetting lease payments.

This paper looks at the impact of prospective hydraulic fracturing for shale gas in the United Kingdom. The UK differs in important ways from the US in that (i) there is no royalty-based compensation for the costs of shale gas extraction as all subterranean petroleum is owned by the Crown since the 1934 Petroleum Act, ${ }^{1}$ and (ii) commercial shale gas extraction has not yet begun,

\footnotetext{
${ }^{1}$ While individual homeowners in the UK will not receive royalty payments from shale development as they do in the US, the UK Onshore Oil and Gas Industrys Community Engagement Charter promises approximately 100,000 as a community benefit per well site where hydraulic fracturing takes place, plus one percent of the future production revenue (Walsh et al., 2011). Moreover, the industry commits to make a voluntary one-off payment of 20,000 for the right to use deep-level land for each unique horizontal well that extends by more than 200 meters. These payments are voluntary but the government reserves powers to make these payments compulsory if firms fail to volunteer.
} 
although Petroleum Exploration and Development Licenses (PEDL) grant the right to explore for shale gas or coal bed methane. Licenses awarded under the 13th licensing round in 2008 mention shale gas exploration projects for the first time. Exploration implies drilling a test well to get accurate estimates of the recoverable shale resources. If firms want to go beyond the exploration stage and actually frack a well, this will require additional consents and planning permissions. ${ }^{2}$ By 2016, a number of exploration wells have been drilled but only one well had been fracked. This situation allows us to take a closer look at the expected costs and benefits of shale gas extraction.

To assess expectations, we employ regression methods and look at whether the expectation of hydraulic fracturing happening in PED license areas was capitalized in house prices. Buying a house is a significant financial commitment and buyers will likely consider the expected costs and benefits of shale gas extraction. To estimate unbiased effects of the expectation of shale gas extraction, we exploit detailed information on every house transaction in the years before and after the 2008 round of licensing. This allows us to compare changes in house prices in the licensed area to changes in the prices of comparable houses outside that area in a difference-in-differences procedure. The approach controls flexibly for all time-invariant local attributes (observed or unobserved) that might be correlated with licensing and house prices. Moreover, it also controls for all time-varying characteristics through the use of well-chosen control locations. Our control group definitions include (i) areas bordering the newly licensed areas; (ii) areas that are not close to the newly licensed areas, but are licensed for exploration in a future round of licensing in 2014, (iii) areas that were licensed before 2008; and (iv) areas where the underlying geology promises shale gas deposits. Comparison of impacts using control areas close to the treatment areas in (i) and further away from the treatment areas in (ii) allows us to assess whether our estimates are threatened by spillovers from treatment to proximate control areas, and violation of the Stable Unit Treatment Value Assumption (SUTVA). We further address the possibility that licensed areas may have experienced trends different from those in non-licensed areas with a triple-difference strategy in which we compare license areas where license holders explicitly mentioned shale gas

\footnotetext{
${ }^{2}$ Drilling requires the landowners consents, planning permissions from the local community, permits from the environmental agencies, positive reviews form the Health and Safety Executive, and permission from the Department of Energy and Climate Change (see DECC 2015b for details). Note that the 2015 Infrastructure Act provides automatic access to deep-level land below 300m for the purpose to exploit petroleum or deep geothermal energy by hydraulic fracturing. As a result, operators do not need access rights from every individual landowner whose land is drilled under at a depth below $300 \mathrm{~m}$.
} 
exploration to license areas where shale gas exploration was not mentioned explicitly.

Our estimates suggest differentiated effects. While licensing itself did not seem to affect house prices, we find a statistically significant negative effect on house prices in areas where shale gas development led to seismic activity. After Cuadrilla one of the companies involved in UK shale gas exploration hydraulically fractured the first (and so far only) well in the UK near Blackpool, two small earthquakes of magnitude 2.3 and 1.5 on the Richter scale were detected by the British Geological Survey in February and May 2011. These were very minor earthquakes, of a magnitude which would not have caused any structural damage, although some residents reported noticeable shaking of windows and furniture. ${ }^{3}$ Earthquakes of this magnitude are not uncommon in the U.K., but subsequent investigations and a well-publicized report, showed that these earthquakes were very probably caused by hydraulic fracturing. Focusing on those areas where hydraulic fracturing likely caused seismic disruption in 2011, we see a pronounced negative effect. Depending on the control group specification, we estimate negative house price effects that range between 2.7 and 4.1 percent following the incidents in 2011. Distance decay specifications show that the effects are centered on the earthquake site and decay rapidly with distance, but there are residual impacts in licensed areas up to $30 \mathrm{~km}$ away. We can further show that the shock to house prices in the earthquake region persisted after 2011, suggesting that fear of fracking-induced seismic activity is not a temporary phenomenon.

Our findings contribute to an ongoing discussion about the expected effects of shale gas extraction. In the UK, media like the Sunday Times (Leake and Thomson, 2014) have reported house price drops in the vicinity of the exploration wells, but these articles were dismissed by the British Department of Energy and Climate Change (DECC) for lack of evidence. DECC went on to counter these news releases, arguing that shale gas operationslike other oil and gas exploration over the past half a centuryshould not affect real estate values (DECC, 2014). Moreover, our results contribute to a rising literature trying to quantify the welfare effects of shale gas activity. Studies that have adopted this approach include Gopalakrishnan and Klaiber (2014), who measure the temporal impact of shale gas wells in Washington County, Pennsylvania, and Muehlenbachs et al. (2015), who use data from all of Pennsylvania to conduct a triple-difference analysis of the effect of shale gas development on groundwater dependent homes, along with a double-difference analysis of

\footnotetext{
${ }^{3}$ http://www.bbc.co.uk/news/uk-england-12930915
} 
the effect on all nearby homes regardless of water source. While that paper finds some evidence of small gains for houses dependent upon public water sources (likely arising from lease payments) it finds evidence of significant negative net effects on groundwater dependent houses. Other research has also recovered evidence of concerns over risks to a households water source (Throupe et al., 2013), or large negative effects on house values more generally (James and James, 2014), although other researchers have found little to no effect (Delgado et al., 2016).

More broadly, our paper connects to the literature that examines earthquakes induced by natural gas extraction (Koster and van Ommeren, 2015), locally undesirable land uses (LULUs) including superfund sites (Greenberg and Hughes, 1992; Kiel and Williams, 2007; Greenstone and Gallagher, 2008; Gamper-Rabindran and Timmins, 2013), brownfield redevelopment (Haninger et al., 2014; Linn, 2013), commercial hog farms (Palmquist et al., 1997), underground storage tanks (Zabel and Guignet, 2012), cancer clusters (Davis, 2004), electric power plants (Davis, 2011), and wind farms (Gibbons, 2015; Dröes and Koster, 2016). In the remainder, we discuss relevant literature in Section 2, followed by a description of the hedonic method in Section 3 and a detailed data description in Section 4. We present our results on the 13th licensing round in Section 5, discuss the house price impacts of expected seismic activity in Section 6, and draw conclusions in Section 7.

\section{Shale Gas Development in the U.K.}

Onshore shale gas production was first proposed in the United Kingdom in 2007. In that process, the Department of Energy and Climate Change (DECC) identified areas in the east and south of England as having potential for shale gas development. In Onshore Oil and Gas Licensing rounds, so called Petroleum Exploration and Development licenses (PEDL) are distributed. Typically, these licenses were granted for conventional oil and gas projects. However, in the 13th Onshore Oil and Gas Licensing round in 2008, unconventional gas exploration using hydraulic fracturing technology became a new option. Figure 1 maps existing license blocks from previous licensing rounds (Panel A), newly licensed blocks in the 13th licensing round in 2008 (Panel B) and blocks that were formally offered to firms in the most recent 14th licensing round in 2014 (Panel C).

PED licenses allow the holder to "search for, bore and get hydrocarbons" subject to access 
rights, planning permission, environment and health \& safety permits. In a licensing round, tranches of $10 \mathrm{~km} \times 10 \mathrm{~km}$ blocks of land are offered by the government for potential exploration and development. Exploration and production (E\&P) companies can apply for a license to drill exploration wells in one or more of these blocks (with only one drill per block). Cuadrilla Resources, IGas and Third Energy are the companies that drilled Shale gas exploration wells by 2014. However, aside from test wells, there has not been any commercial drilling in the UK to date.

The 14th Onshore Oil and Gas Licensing Round was launched on 28 July 2014 and closed on 28 October 2014. According to the Oil \& Gas Authority (OGA), "a total of 95 applications were received from 47 companies covering 295 Ordnance Survey Blocks. Following scrutiny of each applicants competency, financial viability, environmental awareness and geotechnical analysis, and following the decision not to award licenses in Scotland and Wales, 159 blocks were taken forward for further consideration." On 17 December 2015, the OGA announced that 159 license blocks were formally offered under the 14th round. We do not look at the house price impacts of this licensing round in our main specification since it is too recent, but we will utilize the areas offered as a control group for areas offered in the 13th licensing round in one part of our estimation strategy.

Shale gas development is considered a promising energy strategy in the UK for several reasons. First, it can contribute to energy security, reducing the UKs reliance on offshore gas and imported gas. Second, it is thought to support the UKs attempted transition to a low-carbon economy as it emits less CO2 than oil or coal. If shale gas replaced these alternative energy sources it could have a positive effect on the UKs carbon footprint. Third, developments in the U.S. show that commercial drilling can have significant economic benefits not only with respect to possible independence from fossil fuel but also for the local communities where the drilling sites are located. DECC (2013) suggests that "UK shale gas production would be a net benefit to public finances, could attract annual investment of 3.7 billion and support up to 74,000 jobs directly, indirectly and through broader economic stimulus." Additionally, the UK Onshore Oil and Gas Industry (UKOOG) agreed in their 2013 Community Engagement Charter to pay 100,000 to local communities situated near exploratory well sites regardless of whether or not recoverable deposits are found. On top of that, they promised 1 percent of production revenues to communities during the 
production stage, which may amount to $5-10 \mathrm{~m}$ per well over a period of 25 years. Finally, the industry confirmed a voluntary one-off payment of 20,000 per horizontal well to local communities in return for the right to use deep-level land that extends by more than 200 meters. ${ }^{4}$ We do not expect these schemes to be capitalized in house prices for two reasons. First, only one well has been fracked and only a few additional wells were drilled in the UK by 2015. Accordingly, not much money has been paid yet. Second, the expectation of future payments may not be capitalized in house prices because they are not formally guaranteed (though such payments could be made compulsory if companies fail to volunteer) and because they are paid to the community instead of the individual landowner. For community payments to be capitalized in house prices, house buyers would probably need more information about the exact benefits of community projects. For a more detailed discussion of the politics of shale gas and the anti-fracking movement, we refer to a survey essay by Keeler (2015).

Cuadrilla was the first company to receive a license for shale gas exploration along the coast of Lancashire (the dotted red area in the north-west of Figure 1). In August 2010, they started hydraulically fracturing the well Preese Hall 1, which is located near Blackpool. This was the first time that a well had been fracked with modern, high-volume techniques in the UK and as of 2015, it remains the only one. On 1 April 2011, the British Geological Survey (BGS) reported an earthquake of magnitude 2.3 on the Richter scale near Preese Hall 1. Following this event, Cuadrilla installed local seismometer stations around the exploration well that did not observe any further seismic activity. On May 26th, Cuadrilla resumed hydraulic fracturing and only 10 hours later, the BGS reported another earthquake of magnitude 1.5 on the Richter scale. Following these events, Cuadrilla announced on 31st May 2011 a halt due to unstable seismic activity (De Pater and Baisch, 2011). Cuadrilla then commissioned a series of geomechanical studies to investigate the connection between the seismic events and the hydraulic fracturing operations.

The reports concluded that the observed seismic activity "was caused by direct fluid injection into an adjacent fault zone during the treatments, but that the probability of further earthquake activity is low" (Green and Baptie, 2012). A subsequent official UK government report acknowledged that hydraulic fracturing caused the seismic activities. ${ }^{5}$ Despite that, the report did not rec-

\footnotetext{
${ }^{4}$ In 2014, it was enacted that operators do not need access rights from every individual landowner whose land is drilled under at a depth below $300 \mathrm{~m}$.

${ }^{5}$ Appendix Figure A1 illustrates the relationship between the water volume used for fracking the well and the
} 
ommend stopping further operations but rather called for careful monitoring of seismic activities around fracking wells. Subject to stricter rules, the Secretary of State announced on 13 December 2012 that exploratory hydraulic fracturing for shale gas could resume in the UK. However, there were no further wells being fracked by the end of 2015, partly because local communities delayed the planning permission process or refused them. As a reaction, the government announced a number of measures to speed up the permission process for shale gas development projects on 13 August 2015. The Secretary of State can now (i) take the final decision on the appeal from a refusal of local authorities; (ii) call in planning applications for his own determination before local planning authorities have come to a decision; and (iii) determine applications to local planning authorities that are underperforming, i.e. take too long to decide.

\section{Estimation Strategy}

Our aim is firstly to estimate if and by how much house prices are affected when the area in which a house is located is licensed for shale gas exploration and is thus exposed to potential future shale gas development. There are fundamental econometric challenges to this exercise. Places offered, chosen and licensed for shale gas exploration are selected for their potential gas productivity and may therefore differ from unlicensed areas on many dimensions. The licensing decisions may also be influenced by planning considerations and the potential impacts on local residents. Both of these considerations imply that house prices may be different in licensed and unlicensed areas, for reasons other than a causal effect of licensing on prices.

As a first step to address these problems and assess how licensing an area for shale gas development affects house prices, our baseline approach involves regression-based difference-indifferences $(\mathrm{DiD})$ methods that compare the average change in property prices before and after the 13th licensing round to the average house price change in a comparison group. We use the comparison group to show how house prices in a treated unit would have developed in the absence of licenses being issued (the 'counterfactual'). To make this comparison group more similar to the areas licensed for gas exploration, we impose a number of sample restrictions. Firstly, we always exclude urbanized areas that are fundamentally unlike the predominantly rural and semiobserved seismic activity in a diagram published by the BGS. 
rural areas where shale gas exploration is an issue. Specifically, we drop all Output Areas in the top quartile of the population density distribution. We then go on to consider different geographical definitions of the comparison group (based on distance buffers around the license zones) to determine control areas where the trend should closely resemble that in licensed areas.

\subsection{Difference-in-Differences}

We start with a DiD strategy where we use four different control group specifications. All four control groups are mapped in Figure 2, Panels A-D. Our first control group in Panel A is composed of areas that are proximate to the licensed areas but not within those areas. Specifically, we draw a $20 \mathrm{~km}$ buffer around all licensed areas and restrict our estimations to the area that is licensed and the surrounding $20 \mathrm{~km} .{ }^{6}$ The strategy should reduce potential effects from unobserved heterogeneity between license areas and the control group. One concern with this strategy is that areas that are licensed for shale gas development may affect bordering areas negativelybecause e.g. increased truck traffic would spill over into neighboring communitiesor positively if shale gas stimulates the local economy and creates new jobs (Feyrer et al., 2015). Expectations that licensing could extend outward from the currently licensed area might also lead to spatial spillovers. To account for that, we consider a second specification where we use the area that was offered under the future 14th licensing round but we exclude all areas that overlap with the $20 \mathrm{~km}$ buffer used in specification (1). Note that we restrict our observation period to mid-2014 when the 14th licensing round started. The corresponding area covered by this control group is mapped in Panel B.

Panel C presents a control group specification where we use all existing license areas. Prior to the advances in drilling technology that made hydraulic fracturing lucrative, license holders engaged in conventional oil and gas exploration. With the rise of hydraulic fracturing technologies, existing PED licenses could also be used for unconventional shale gas exploration. However, while a license grants exclusivity to the holder within the licensed area, it does not imply a right to drill a well. Initial seismic investigations can be undertaken but further steps towards exploration and exploitation require consent from the national authority DECC and an additional planning permission from the relevant Mineral Planning Authority (MPA). One can therefore think

\footnotetext{
${ }^{6}$ Unreported specifications where we use a $10 \mathrm{~km}$ buffer lead to very similar results.
} 
of the already licensed areas as regions where some consent for oil and gas development has been granted. Using them as control group therefore accounts for unobserved effects that are specific to areas that get licensed. ${ }^{7}$ While PED licenses allow shale gas exploration (conditional on consent from the national and local authorities), exploration will only happen in areas with the right underlying geology. To account for that, we exploit the exogenous assignment of geology to create a fourth control group that allows us to compare licensed and non-licensed areas with the same underlying geology that is promising for shale gas development (Panel D). Information on geological features that are promising for shale gas development stems from the British Geological Survey (BGS). This strategy accounts for unobserved license area effects and it also accounts for geological specificities. For instance, if the underlying shale rock implied better (or worse) natural amenities we would face a bias if these amenities were captured in house prices.

To implement our strategy, we exploit house transaction data for the period January 2005 to June 2014 and estimate the following baseline equation:

$$
\ln P_{i t}=\alpha_{i}+\kappa_{t}+\rho \cdot \text { License }_{i} \times \text { Post }_{t}+X_{i t} \delta+\epsilon_{i t}
$$

The dependent variable is the log of the mean property transaction price observed in Census Output Area i in quarter t. Output Areas (OAs) are spatial units defined in the 2001 census that contain on average 10 postcodes at the 6 digit level with an average of 50 households. $\alpha_{i}$ indicates a vector of output area fixed effects. $\kappa_{t}$ indicates a full set of quarteryear dummies that control for general time trends in house prices. In an alternative specification, we deflate house prices with an annual price index instead of using this flexible time trend. $\rho$ is the coefficient of interest that will tell us how much the house price is affected by the licensing. The corresponding regressor is an interaction between two dummy variables. License $e_{i}$ takes the value 1 if a house is located within an area that has been licensed for shale gas development under the 13th licensing round in 2008 and Post $_{t}$ takes the value 1 if a house was sold after the licensing round in February 2008 (i.e., after the first quarter of 2008). Consequently, the interaction is unity in the treatment locations that were licensed for shale gas development after 2008. Note that we do not include the components of the interaction term (i.e., License $_{i}$ and Post $_{t}$ ) in this flexible specification because

\footnotetext{
${ }^{7}$ In additional unreported specifications we considered smaller distance buffers. We find similar effects.
} 
they are already controlled for by the output area and time dummy variables. Our main coefficient of interest is therefore on the interaction term, which measures the average treatment effect on the treated (ATT) associated with shale gas licensing. $X_{i t}$ is a matrix of covariates including sets of control variables for the proportion of sales of detached, semi-detached, and terraced houses or flat/maisonette. ${ }^{8}$ Beyond that, we interact year dummies with (i) four elevation groups $(0<e \leq$ $25 m ; 25 m<e \leq 50 m ; 50 m<e \leq 100 m$; $e>100 m$ ) to capture terrain differences; (ii) the $\log$ of distance to the coast as well as distance to the next center with 1,000,10,000, and 50,000 inhabitants to allow for changes in the valuation of proximity to the coast or centers; and (iii) indicators for 10 regions to allow for different house price trends across regions. ${ }^{9}$ These controls along with the output area fixed effects, should capture unobserved geographic differences that simultaneously affect the (un)attractiveness of an area and the availability of shale gas. Across all specifications, standard errors are clustered on the output area level. ${ }^{10}$

In specification (1), $\rho$ estimates the average treatment effect on the treated for the post-period from 2008-2014. However, as discussed in Section 2, two earthquakes occurred early in 2011 which were subsequently attributed to Cuadrillas shale gas exploration well Preese Hall 1 near Blackpool. This seismic activity attracted substantial media attention and it took one year of investigations before the government lifted the ban from all exploration activities. This may have been bad publicity for shale gas developers and we allow this potential negative effect to be captured separately. To assess this additional event, we estimate the following extended equation:

$$
\ln P_{i t}=\alpha_{i}+\kappa_{t}+\sum_{j} \rho_{j} \cdot \text { License }_{i} \times \text { Post }_{t j}+X_{i t} \delta+\epsilon_{i t}
$$

Where $j$ distinguishes the two events-licensing and earthquake-such that Post $_{t j}$ takes the value 1 starting in the quarter after the event (i.e., from the 2nd quarter of 2008 and the 3rd quarter of 2011 on). The interaction of Post ${ }_{t j}$ with License $_{i}$ then gives us the event specific interaction that is unity if we observe a house transaction in a licensing area in the respective post-period $j$. The coefficient $\rho_{j}$ quantifies the average house price effect after the respective event. We consider the

\footnotetext{
${ }^{8}$ We will present additional specifications were we use property transaction data from Nationwide which allow us to control for further house attributes.

${ }^{9}$ The regions are North East, Yorkshire and the Humber, North West, East Midlands, West Midlands, East Anglia, South East, South West, Wales, London.

${ }^{10}$ Alternative specifications where we allow for common shocks within larger spatial units do not change our results. We present specifications where we cluster standard errors on the level of travel to work areas in the robustness checks.
} 
same controls as in specification 1 and cluster our standard errors on the level of Output Areas. Main effects are covered by the output area fixed effects and time dummies.

\subsection{Difference-in-Difference-in-Differences}

One last concern is that PED licenses are not limited to unconventional shale gas exploration. They also cover conventional exploration methods. Conventional gas exploration methods have been used for almost 50 years and are less likely to be of concern in terms of the potential for groundwater contamination, air pollution, and other local disamenities. As a result, combined estimations that consider licenses for conventional and unconventional exploration jointly may be downward biased. To account for that, we exploit additional information provided by DECC on the type of exploration project to identify a separate effect for areas which are licensed for shale gas exploration. We estimate the following triple-difference equation:

$$
\begin{array}{r}
\operatorname{lnP}_{i t}=\alpha_{i}+\kappa_{t}+\sum_{j} \rho_{j} \cdot \text { License }_{i} \times \text { Post }_{t j}+\sum_{j} \gamma_{j} \cdot \text { ShaleLicense }_{i} \times \text { Post }_{t j}+ \\
+\sum_{j} \theta_{j} \cdot \text { License }_{i} \times \text { ShaleLicense }_{i} \times \text { Post }_{t j}+X_{i t} \delta+\epsilon_{i t}
\end{array}
$$

Since ShaleGasLicense $\subseteq$ License, $\gamma_{j}=\theta_{j}$ and the equation simplifies to:

$$
\begin{aligned}
& \ln P_{i t}=\alpha_{i}+\kappa_{t}+\sum_{j} \rho_{j} \cdot \text { License }_{i} \times \text { Post }_{t j}+ \\
& +\sum_{j} \gamma_{j} \cdot \text { ShaleLicense }_{i} \times \text { Post }_{t j}+X_{i t} \delta+\epsilon_{i t}
\end{aligned}
$$

Where $\gamma_{j}$ now denotes the coefficients of interest. These coefficients measure whether areas with the higher likelihood of experiencing shale gas exploration experienced stronger house price effects than other licensing areas where conventional exploration projects took place. Note that this specification controls for differences in house price trends between areas that were licensed for exploration (either conventional or shale gas) and control areas and the non-exploration control areas. For instance, licensing areas may be environmentally less attractive and thus follow a 
different house price trend. Or areas that receive licenses may be economically less vibrant and seek gas exploration and development since it may create jobs or generate municipal income. Following the same logic, we can exploit the fact that license areas where the earthquake happened are a subset of the shale gas licensed regions (Earthquake $\subseteq$ ShaleLicense). To identify a markup in those license areas where the earthquake happened, we can simply add another interaction term $\sum_{j} \nu_{j} \cdot$ Earthquake $_{i} \times$ Post $_{t j}$ to Equation 4 where $\nu_{j}$ now measures a potential difference in the house prices effects in those license areas that experienced the earthquake. This specification controls for specific house price trends in areas that were licensed for shale gas development.

\section{Data}

Housing transaction data were taken from the Land Registry Price Paid Data provided by the UK government for England and Wales. The data go back to 1995, but we restricted the data to the period between the first quarter of 2005 and the second quarter of 2014 for the purpose of this research. We further drop all observations that are the top and bottom $1 \%$ of the transaction prices and we exclude in all specifications Output Areas in the top quartile of the population density distribution and Output Areas in major and minor conurbations because these concentrated areas are likely inner-city areas which are fundamentally different (possibly in unobservable ways) from the rural areas where drilling tends to happen. The data include information on the sales price, four property types detached, semi-detached, terraced or flat/maisonette-whether the property is new, and whether it is sold on freehold or leasehold basis. Housing transactions are mapped into 2001 Census Output Areas and aggregated to mean output area-by-quarter cells. This leaves us with a panel of quarterly sales at the level of 92,663 Output Areas. The panel is unbalanced because we do not observe sales for every Output Area in every quarter. Appendix Table A1 provides descriptive statistics of our data separated by license area, period, and the respective control groups.

We supplement the land registry data with property sales data from the Nationwide building society, which covers about 15 percent of the transactions reported in the land registry database. These data allow us to consider additional house characteristics including floor area, the number of bathrooms and bedrooms, housing tenure and whether the house comes with a garage or not. 
Further controls for socio-economic characteristics at the output area level are taken from the 2001 Census. Since our specifications all include output-area fixed effects, time invariant output area characteristics do not play a role. To account for potentially time varying effects, we present robustness checks where we interact additional characteristics with flexible time trends.

Information on the areas licensed under the 13th and 14th licensing round are published by the UK Oil and Gas Authority. These data include detailed information on the licensing blocks, the proposed exploration, and the companies that hold licenses. The data further include information from the British Geological Survey on areas whose geology renders them promising for shale gas development. We use these data to determine whether Output Areas are within the licensed area and whether the license covers shale gas development.

Lastly, we calculate a number of geographic control variables to account for the geographic location of an output area. These involve four elevation categories $(0<e \leq 25 \mathrm{~m} ; 25 \mathrm{~m}<e \leq 50 \mathrm{~m}$; $50 m<e \leq 100 m ; e>100 m$ ) to capture terrain differences and interactions between year and the $\log$ of distance to the coast, distance to the next center with 1,000, 10,000, and 50,000 inhabitants.

\section{Results}

\subsection{Baseline}

Table 1 and Table 2 present our baseline specifications for the four control group definitions described above. Panel A uses as control group a $20 \mathrm{~km}$ buffer around the area licensed under the 13th licensing round. The control group in Panel B is the area under consideration for the 14th licensing round minus the $20 \mathrm{~km}$ buffer in Panel A. In Panel C, we present specifications with areas that were licensed under previous rounds as control group. Finally, in Panel D, we use information on the underlying geology to distinguish between areas where shale gas development is more or less likely to happen.

We present two specifications in all of our regressions. The first one contains a baseline set of controls that merely accounts for time trends (quarter-by-year dummies), output area fixed effects, and basic house attributes (share of four property types, share of new properties and the share of properties sold as freehold) and a second one were we additionally control for geographic control variables interacted with year dummies to allow for house prices to vary with the geographic 
location of an output area (four elevation categories, log of distance to the coast, distance to the next center with 1,000, 10,000, and 50,000 inhabitants, and dummies for 10 regions).

Our baseline specification in columns 1 and 2 is a simple difference-in-differences, where the coefficient of interest tells us whether licensed areas experienced a house price drop in the post period from the second quarter of 2008 till the second quarter of 2015. Among licensed areas, we distinguish all licenses granted in 2008 (License) and a subset of licenses where shale gas development was mentioned (Shale) and within this group the areas where the earthquake happened (Earthquake). The estimated coefficient on licensed areas post-2008 is small and ranges between a positive effect of 1.1 percent and a negative effect of 0.8 percent across Panels A-D. By contrast, we see a persistently negative effect post-2008 for those regions where shale gas development was mentioned. The effects indicate negative house price effects between 2.9 and 3.1 percent. In column 2, we extend our set of control variables and we find similarly small house price effects between 0.4 and 1.1 percent in the licensed areas overall and negative house price effects between 2.1 and 2.8 percent in the areas where shale gas development was mentioned.

In columns 3 and 4, we split the after-period up and allow for a different effect in licensed areas after the first instance of hydraulically fracturing a well in the UK resulted in two earthquakes. Doing so shows that the negative effect in areas where shale gas development was mentioned is driven by the one area where shale gas development took place and caused seismic activities. Accounting for the full set of controls, those areas where the first hydraulic fracturing attempt caused two earthquakes in 2011 faced a negative house shock post-2011 that ranges between 3.5 and 4.8 percent while the effect in licensed areas and licensed areas where shale gas was mentioned is negligible.

Finally, in columns 5-6, we present our preferred specification where we additionally include post-2008 interactions for the earthquake regions and post-2011 for the non-earthquake regions. The specification in column 6 with the full set of controls suggests that the negative house price effects were predominantly driven by the time after the seismic incidents in 2011 and it is restricted to the earthquake region. Our estimates suggest that house prices in the earthquake area fell post2011 by 3.9-4.7 percent. There is some indication that house prices in the earthquake area might have started to fall after 2008 which could point to a negative effect of drilling and fracking that is independent of the seismic activities. However, since this interpretation is only supported by 
Panel B we do not consider it conclusive.

For ease of interpretation, we summarize the effects from the full specification in Column 6 for the four control group specifications and the post-2008 (light bars) and post-2011 (dark bars) period in Figure 3. The figures illustrate the pronounced earthquake effect after 2011 while there is no evidence of negative effects in licensed areas or shale areas. Unlike the other Panels, Panel B suggests a pronounced negative house price effect of 3.2 percent in the earthquake areas, pointing to some difference between our control region specifications. However, this does not affect our conclusions that seismic activity was the main driver of the sharp drop in house prices after 2011.

Overall, these results suggest that shale gas exploration was only perceived as a disamenity as a result of the earthquake, and in the areas where the earthquake took place. Another interpretation is that the earthquake raised peoples awareness of shale gas exploration and the potential risks-but only in proximity to the location where the incident happened. In the following, we will test the robustness of our findings and take a closer look at the effect in proximity to the earthquake location.

\subsection{Robustness}

We will now consider a number of additional specifications to probe the robustness of our preferred findings. The results are displayed in Table 3. In column 1, we deflate house prices with a price index for the ten regions used to calculate region trends with 2008 as base year. In column 2, we include socio-demographic characteristics from the 2001 census interacted with a 4th-order polynomial of year-trends to allow for time-variant differences between Output Areas that are not captured by the output area fixed effects, the limited number of time-variant house characteristics

or the region trends. Specifically, we include controls for the proportion of individuals without basic high school qualifications, the proportion of highly qualified individuals with a university degree, the proportion of individuals born in the UK, the proportion of individuals of white ethnicity, the proportion of employed individuals, the proportion of individuals who live in social housing, and the measure of the size of the output area.

In column 3, we control for an interaction between the Output Areas XY-coordinates and a 4th-order polynomial of year-trends and in column 4, we interact the house characteristics with year-dummies to allow for different time trends. Finally, in column 5, we present a specification 
where we cluster our standard errors on the level of 76 travel to work areas.

The results after including these control variables are very similar to those described in Table 1 and Table 2. For the $20 \mathrm{~km}$ buffer in Panel A, we find negative house price effects between 3.0 and 4.2 percent; in Panel B, they range between a negative effect of 3.5 and 4.6; in Panel C we find negative house price effects between 3.6 and 4.7 percent; and in Panel D, the house price drop varies between 3.1-4.1 percent. Clustering the standard errors on a very conservative level increases the standard errors slightly but our results remain highly significant. Overall, the robustness checks give us a most conservative estimate of a 3.0 percent reduction and a least conservative effect of 4.7 percent.

So far, our regressions have relied on data from the Land Registry database. This is the most comprehensive dataset on property transactions available but it comes with a fairly limited number of house-level control variables. To assess whether unobserved property characteristics bias our estimates, we also looked at property transactions from the Nationwide building society, which includes a more comprehensive set of housing characteristics and so allows us to control more carefully for physical structure. However, this dataset covers about 15 percent of all transactions reported in the register data. Repeating our analysis on this data set yields broadly similar results to those from the register data, with a negative effect that ranges between -1.2 and -3.0 percent in those license areas that experienced the earthquake. However, as might be expected from the smaller sample, the individual coefficients are generally less precisely measured and more sensitive to the choice of control group and specification. The full results using this dataset are shown in Appendix Table A2.

\subsection{Interactive fixed effects}

Despite our comprehensive set of control variables, it may be the case that highly localized shocks are correlated with our different licensing treatments. Ideally, we would like to account for that using flexible output-area specific trends. While we cannot include interactions between time and output areas since they would be collinear with our treatment dummies, we could include interactions between output area dummies and polynomial time trends. But given that we are looking at several thousand output areas, this is computationally intensive. An alternative way to absorb an extended set of unobserved and potentially biasing local effects is to use Bai (2009) 
interactive effect methods as suggested by Gobillon and Magnac (2016)).

The idea is to extract a factor $\lambda_{i}^{\prime} F_{t}$ from the error term $\epsilon_{i t}$ in the baseline estimation equation (4) where $F_{t}(r \times 1)$ represents a deterministic time-varying common factor which can have a different effects on every output area $i$. These heterogeneous effects are captured by the factor loading $\lambda_{i}(r \times 1)$. Since the regressors are allowed to arbitrarily correlate with this factor, it further reduces the possibility that unobserved local shocks that were captured by the error term are causing an omitted variable bias. Another useful feature is that the factors control for cross-sectional correlation because each cross-section shares the same $F_{t}$.

Since we are working with an unbalanced panel, we follow Bai et al. (2015) and assume the following structure: $\epsilon_{i t}=\alpha_{i}+\lambda_{i}^{\prime} F_{t}+e_{i t}$. Bai et al. (2015) show that including an Output Area fixed effect $\alpha_{i}$ enhances the efficiency, and one can further see from this specification that assuming $r=1$ reduces the model to a standard fixed effects model. $\lambda$ and $F$ are estimated using the LS-FPCA algorithm discussed in Bai et al. (2015).

The results of this additional robustness check are presented in Table 4. As discussed in Gobillon and Magnac (2016), we experiment with the number of factors $r$ included in the model and find very similar results using 2, 3 or 4 factors. In the table, we present the specification where we use $r=2$ factors. Reassuringly, we see that flexibly accounting for heterogeneous local shocks leads to qualitatively similar results. For our four specifications, we continue to find negative house price effects in the range of 3.2 and 4.1 percent.

\subsection{Balancing Tests}

This section explores which other observable house characteristics in an Output Area changed around the time that our treatment areas were licensed in 2008. ${ }^{11}$ This should give us some idea about potentially biasing effects from unobserved characteristics across Output Areas. Table A4, Column 5 presents the results of regressions using different house characteristics as outcomes (note that we do not control for other house characteristics in this specification). Since the land registry data come with a limited number of house characteristics, we supplement our balancing tests with Nationwide data.

\footnotetext{
${ }^{11}$ In unreported specifications, we include post-2008 and post-2011 interactions. As in the post-2008 interactions, we cannot see any differences in the observable characteristics (apart form the number of sales), the estimated effects are all zero.
} 
Looking at the diff-in-diff and triple-difference coefficients, we see mostly insignificant and economically irrelevant effects. Our main concern would be that the observed price change is being driven by the sale of lower quality houses rather than by the expectation of shale gas development. We find no indication for such a bias. We only find some indication that the share of sales of terraced houses has increased while the share of flats has fallen, and that there is shift towards slight older properties. However, these small changes cannot possibly account for the price reductions seen in our main estimates. For example, the changes in the shares of different types of houses in sample $C$ corresponding to the earthquake event would imply an average price decrease of around 0.24 percent, whereas the price effect we found in Table $1 \mathrm{~b}$ was around 4.7 percent.

\section{Extensions}

\subsection{Distance Decay Effects around Preese Hall 1 Well}

To understand the extent of the observed effect around the Preese Hall 1 site where the earthquake happened, we now turn to a set of distance decay models. Figure 4 shows distance rings set to $10,20,30,40,50,75,100 \mathrm{~km}$ from the well that induced the earthquake. We can see that a maximum distance of $100 \mathrm{~km}$ includes the Bowland Basin in the north-west (grey shaded area) which, according to a 2013 study by the British Geological Survey (Andrews, 2013), holds significant shale gas resources. Their gas-in-place assessment suggests 37.6 trillion cubic meters (tcm) and potentially recoverable resources of 1,800-13,000 billion cubic meters (bcm) at a recovery factor of $8-20 \%$ which is common for the U.S. To put this into perspective: DECC suggest an annual UK gas consumption of $70 \mathrm{bcm}$ for 2014 (DECC, 2015a). The importance of the Bowland Basin for UK shale gas development is further underlined by the fact that it is the only area where shale gas exploration wells have been drilled by 2015. Our distance decay estimations therefore serve two functions. Firstly, if the estimated price reductions are caused by the Preese Hall earthquakes, we would expect to see the price effects declining rapidly with distance from the drill site. Secondly, any effects at higher distance radii may say something about the extent to which the 2011 seismic events spread fear of fracking into the Bowland Basin area. To estimate the distance decay effect, we modify our estimation equation slightly and estimate the change in the house price trend after 
the earthquake incidence in 2011. In a first specification, we estimate:

$$
\ln P_{i t}=\alpha_{i}+\kappa_{t}+\sum_{r} \tau_{r} \cdot \text { Dist }_{i r} \times \text { Post }_{t}+X_{i t} \delta+\epsilon_{i t}
$$

For distance rings $r \in[0,10),[10,20),[20,30),[30,40),[40,50),[50,75)$. The $[75,100) \mathrm{km}$ ring is the reference group. In this estimation, $\tau_{r}$ will tell us the effect of the earthquake shock on house prices in the six different distance rings thus revealing any distance decay patterns. In a second step, we extend this estimation equation and allow within distance rings for differential effects between licensed and non-licensed areas. Specifically, we estimate:

$$
\ln P_{i t}=\alpha_{i}+\kappa_{t}+\sum_{r} \tau_{r} \cdot \text { Dist }_{i r} \times \text { Post }_{t}+\sum_{r} \phi_{r} \cdot \text { License }_{i} \times \text { Dist }_{i r} \times \text { Post }_{t}+X_{i t} \delta+\epsilon_{i t}
$$

Where $\phi_{r}$ will now tell us whether licensed areas within a given distance ring were affected differently than non-licensed areas. We condition our regressions on the same sets of controls as before.

To facilitate interpretation, we present the results of our distance decay regressions in a graph. Panel A of Figure 5 shows results for a distance decay specification where we measure changes in house price effects following the 2011 seismic incidences relative to a pre-period form 2005-2011 in the distance rings described above. All estimates are reported with 95\% confidence intervals. We see negative house price effects over the entire distance. However, it is not clear whether this effect is driven by the earthquake or a spurious trend. To identify how the earthquake spread a fear of fracking, we estimate a second specification where we control for changes within a given distance ring after the earthquake and then look for an on-top effect of licensed areas within this distance ring. Doing so shows a similar pattern but suggests effects that only reach out to the $(20,30]$ bin. Beyond that, the license areas exhibit positive price trends relative to the unlicensed areas, although the combined effect from Panel A and B is around zero and it is not clear to what extent these patterns at greater distance thresholds can really be attributed to the fracking and earthquake event. Overall, there appear to be distinct local impacts, but there is no clear evidence of any spillovers into the wider area. Note, the effects in the $10-20 \mathrm{~km}$ band in Panel B are imprecise because most of the areas in that band are licensed for exploration. Regression tables with the 
estimated coefficients can be found in Appendix Table A3, Column 1 and 2. ${ }^{12}$

\subsection{Placebo Estimations}

In a first placebo exercise, we look at locations across the UK that experienced earthquakes of similar magnitude (a range between 1.5 and 2.3) the year before the fracking-induced earthquake happened, i.e. between 2010/Q1 and 2011/Q1. This leaves us with 22 earthquakes of similar magnitude between 2010/Q4 and 2011/Q3. ${ }^{13}$ In Figure 6, Panel A, earthquake locations are indicated by a star symbol. Looking at the effects of seismic activity that is not caused by fracking will help us understand whether the occurrence of an earthquake per se is considered a disamenity that is reflected in house prices. In a second placebo check, we estimate distance decay effects around 78 conventional wells drilled between 2011/Q1 and 2015/Q2. ${ }^{14}$ These locations are indicated by a square symbol in Figure 6, Panel B. If there was any disamenity related to drilling a well (but not fracking it), this regression should reveal it.

Figure 7, Panel A shows the estimated coefficients of the placebo earthquakes using regression equation (5). The only difference is that we include an additional set of distance ring-by-year dummies to flexibly account for different house-price trends around earthquake locations. Further note that we drop all Output Areas within 40km of Preese Hall 1 and that we do not consider the intensity of an output areas earthquake exposure i.e. an output area is treated after the first earthquake has happened in a given distance and we do not account for additional earthquake shocks in subsequent periods in the same distance bin. Regression tables with the estimated coefficients can be found in Appendix Table A3, column 3.

There is no indication of a negative house price effect related to the earthquakes. This is not surprising since an earthquake of magnitude 1.5-2.3 can hardly be felt. This placebo exercise suggests that the post-fracking-earthquake effect we identify is not driven by a general fear of earthquakes. It is more likely that the earthquakes and media attention surrounding them made the risks associated with fracking more salient, and it is the fear of these risks that is capitalized in house prices.

\footnotetext{
${ }^{12}$ Note that the control area within $10 \mathrm{~km}$ of Preese Hall 1 has been licensed for oil and gas exploration before 2008.

${ }^{13}$ Data on the magnitude and location of earthquakes are published by the British Geological Survey in the Bulletin of British Earthquakes for 2010 and 2011.

${ }^{14}$ Information on well drilling is published by DECC.
} 
In Panel B, we repeat the regression specification used in Panel A for conventional gas drilling sites. Regression tables with the estimated coefficients are presented in Appendix Table A3, Column 4. Again we find no indication of a negative house price effect related to well-drilling activities. If anything, there is a mildly positive effect in close proximity. This second placebo exercise suggests that well-drilling activities for conventional oil and gas exploration do not raise any fear and we do not see any house price reaction. Taken together, these two placebo exercises support our interpretation of the effect around Preese Hall 1. The observed effect is likely driven by a fear of future seismic activities induced by fracking.

\subsection{Event Study Estimation}

One assumption underlying our DiD estimations is that the different control groups will describe how the treated regions would have developed in the absence of licensing. To shed more light on the price trends before and after the beginning of our treatment period, we present an event study with 2011 as base year and interactions between the different license area definitions in the pre-period (2005/Q1-2010/Q1) and the post-period (2011/Q2-2015/Q4). Note that 2011/Q1 is the omitted category and that we extend the time period to 2015/Q4 in this exercise. Doing so will tell us whether house price trends were affected by the 14th licensing round that started in 2014 or by the introduction of the Community Charter that promised payments to communities that allow fracking in 2013. The estimation equation for these dynamic effects is a modification of equation (4). Instead of interacting the license, shale gas and earthquake dummies with post-2008 and post-2011 dummies, we now interact them with quarter-by-year-indicators, $D_{t}$, in the preand post-periods:

$$
\begin{array}{r}
\ln P_{i t}=\alpha_{i}+\kappa_{t}+\sum_{t \neq 2011, Q 1} \omega_{t} \cdot \text { License }_{i} \times D_{t}+\sum_{t \neq 2011, Q 1} \pi_{t} \cdot \text { ShaleLicense }_{i} \times D_{t}+ \\
+\sum_{t \neq 2011, Q 1} \eta_{t} \cdot \text { Earthquake }_{i} \times D_{t}+X_{i t} \delta+\epsilon_{i t}
\end{array}
$$

We present the result of the event study for all four specifications in Figure 8. The long-dashed line represents the event time indicators $\omega_{t}$ for the licensed areas, the short-dashed line the event time indicators $\pi_{t}$ for the licensed areas where shale gas development was mentioned, and the 
solid line represents the event time indicators $\eta_{t}$ for the earthquake region.

The graph contains several messages. First, we see not much happening in the license and shale gas group over time (the table with detailed coefficients and standard errors is available from the authors upon request). By contrast, the earthquake group region experienced a drop in house prices after the seismic activity in 2011. Importantly, this effect is persistent though slightly recovering at the end of the period between 2011 and 2015, suggesting that fear of fracking-induced seismic activity is not a temporary phenomenon. In the pre-period, we do not see a strong indication of a trend before 2010. Around this time, we see the beginning of a dip in the earthquake region which might indicate some disamenity from drilling and fracking activities before the earthquake. However, note that this small initial dip is not significant and thus indicative at best.

Second, we do not see an indication that announcing the community charter changed the house price trend systematically. To support this, Appendix Table A4 shows a variation of our baseline estimates where we additionally include a post-2013 dummy interacted with our three treatment indicators. The coefficients for the post-2013 period are significant and range between a negative house price effect of 2.7 and 3.6 percent-i.e. slightly smaller than the post-2011 effects. This suggests that the introduction of the community charter did not have the intended effect. One explanation why we observe no effect is that there have not been any exploration activities going on since 2013. Consequently, there were no payments to communities that could have been perceived as benefits of shale gas development. An alternative explanation is that the scheme is not publicly known, not formally guaranteed, or not generous enough. The latter case would point to the need to communicate and institutionalize the community engagement charter and it would also require a better understanding of the cumulative costs of shale gas development that have to be compensated by corresponding payments to local communities.

\section{Discussion and Conclusion}

We measure the consequences of the 13th round of onshore oil and gas licensing on property values across different control groups. By carefully defining control groups, our estimates account for a number of fixed and time-varying factors that could possibly confound the effect of nearby licensing. In particular, we utilize a difference-in-differences identification strategy to quantify the 
change in housing prices attributable to the issuance of licenses in 2008 and the subsequent earthquake in 2011. Our estimations suggest that on average, areas that were licensed for conventional and unconventional oil and gas exploration did not experience any house price effects. Only those areas where hydraulic fracturing caused seismic activity suffer from a house price drop of up to 5 percent.

A long line of theoretical literature on hedonic models and empirical applications has shown that these price effects can be interpreted as home-buyers marginal willingness to pay to avoid (or marginal willingness to accept) exposure to shale gas development in the vicinity of their homes. ${ }^{15}$ This interpretation requires some quite strong assumptions and approximations, but if applied in our case it implies that an average household in the earthquake area would be willing to pay between 310 and 374 (in 2008-prices) per year, depending on the specification in Table 1 and Table 2, Column 6, to avoid areas where fracking induced seismic activity. Note that we use the smallest (0.039) and largest (0.047) estimated difference-in-difference-in-difference coefficients for these back-of-the-envelope calculations. The implicit assumption is that the other estimated effects in license and shale areas are potentially spurious trends. If these trends were not spurious, we would compare the effect of the earthquake in licensed shale areas relative to non-licensed areas. Put differently, we would cumulate the coefficients on License Area, Shale and Earthquake after 2011 which gives us effects between 0.027-0.045. In this case, the average household in the earthquake area would be willing to pay between 219 and 365 (in 2008-prices) per year to avoid areas where fracking induced seismic activity.

Given 22,749 transaction in the period after the earthquake, i.e. between the third quarter of 2011 and the second quarter of 2014, we arrive at a cumulative house price loss that ranges between 141 and 170 million (in 2008-prices) using the DDD coefficients and 100-166 million using the cumulative effects. We can think of these numbers as a lower bound because fear of frackinginduced seismic activity does not just affect houses that are being sold. It also devalues houses

\footnotetext{
${ }^{15}$ Rosen (1974) provides the seminal theoretical analysis. The challenges to recovering information on underlying consumer preferences from empirical analysis are discussed in Brown and Rosen (1982), Mendelsohn (1985), Bartik (1987), Epple (1987), Ekeland et al. (2004), Bajari and Benkard (2005), Heckman et al. (2010), Bishop and Timmins (2011) and Yinger (2015). Other empirical applications include, to name just a few: valuations of air quality (Chay and Greenstone, 2005; Bajari et al., 2012; Bui and Mayer, 2003; Harrison and Rubinfeld, 1978; Ronald G. Ridker, 1967), water quality (Walsh et al., 2011; Poor et al., 2007; Leggett and Bockstael, 2000), school quality (Black, 1999; Gibbons et al., 2013), crime ((Gibbons, 2004; Linden and Rockoff, 2008; Pope, 2008a), airport noise (Andersson et al., 2010; Pope, 2008b) and wind turbines (Gibbons, 2015).
} 
that are not being sold and it may even devalue land without houses. The 2011 census suggest that there are 145,018 households in the earthquake area which implies that the house price loss could be more than 6 times larger and our distance decay specifications further suggest that this effect is not limited to area where the earthquake happened.

These approximated numbers are clearly substantial, even more so since the effects of actual shale gas exploration have not yet been experienced and the results were solely a reaction founded on house owners fears. The implication is that there are psychic costs associated with fracking, which may need to be compensated even when there is no actual damage on which to base a claim. As the United Kingdom is on the verge of initiating further shale gas exploration projects, it is important to consider this evidence of impacts on homeowner valuations in the public policy debate. These estimated costs could be offset to some extent, at the community level, by payments made through the Community Engagement Charter (UKOOG, 2013), but exactly how these payments would be distributed is unknown at this time. However, our estimates suggest that the size of the appropriate compensatory payments is well in excess of the level of payments set in the existing Community Engagement Charter which offers payments of 100,000 to communities where exploration takes place and the additional (voluntary) industry commitment to pay 20,000 for every unique horizontal well.

At the beginning of 2016, a total of 159 blocks were formally offered to successful applicants under the 14th Onshore Oil and Gas Licensing Round. Given the vibrant debate about the size of local disamenities associated with expected drilling activities, estimates like ours are important to inform the policy debate. In the light of the above findings, we conclude that the existing voluntary payments are likely too low to compensate house owners. Further, it seems more appropriate to target them to areas where wells have actually been fracked or where seismic activity has occurred instead of compensating all exploration areas. A final concern relates to the legal force of the voluntary compensation schemes paid to communities. Since these payments are not legally binding and it is not clear how benefits will be distributed, house owners may value these payments less than individual compensation payments. Formal regulation to guarantee payments to individual house owners or for specific community projects could help overcome this problem. 


\section{References}

Andersson, H., L. Jonsson, and M. gren (2010). Property prices and exposure to multiple noise sources: Hedonic regression with road and railway noise. Environmental $\mathcal{E}$ Resource Economics 45(1), 73-89.

Andrews, I. (2013). The carboniferous bowland shale gas study: geology and resource estimation. Technical report, British Geological Survey for Department of Energy and Climate Change, London, UK.

Bai, J. (2009). Panel data models with interactive fixed effects. Econometrica 77(4), 1229-1279.

Bai, J., Y. Liao, and J. Yang (2015). Unbalanced panel data models with interactive effects.

Bajari, P. and C. L. Benkard (2005). Demand estimation with heterogeneous consumers and unobserved product characteristics: A hedonic approach. Journal of Political Economy 113(6), 12391276.

Bajari, P., J. Fruehwirth, K. i. Kim, and C. Timmins (2012). A rational expectations approach to hedonic price regressions with time-varying unobserved product attributes: The price of pollution. American Economic Review 102(5), 1898-1926.

Bartik, T. (1987). The estimation of demand parameters in hedonic price models. Journal of Political Economy 95(1), 81-88.

Bishop, K. and C. Timmins (2011). Hedonic prices and implicit markets: Estimating marginal willingness to pay for differentiated products without instrumental variables. NBER Working Papers 17611, National Bureau of Economic Research, Inc.

Black, S. E. (1999). Do better schools matter? parental valuation of elementary education. The Quarterly Journal of Economics 114(2), 577-599.

Brown, J. N. and H. Rosen (1982). On the estimation of structural hedonic price models. Econometrica 50(3), 765-68.

Bui, L. and C. Mayer (2003). Regulation and capitalization of environmental amenities: Evidence from the toxic release inventory in massachusetts. The Review of Economics and Statistics 85(3), 693-708.

Caulton, D. R., P. B. Shepson, R. L. Santoro, J. P. Sparks, R. W. Howarth, A. R. Ingraffea, M. O. L. Cambaliza, C. Sweeney, A. Karion, K. J. Davis, B. H. Stirm, S. A. Montzka, and B. R. Miller (2014). Toward a better understanding and quantification of methane emissions from shale gas development. Proceedings of the National Academy of Sciences 111(17), 6237-6242.

Chay, K. and M. Greenstone (2005). Does air quality matter? evidence from the housing market. Journal of Political Economy 113(2), 376-424. 
Colborn, T., K. S. L. H. and C. Kwiatkowski (2014). An exploratory study of air quality near natural gas operations. Human and Ecological Risk Assessment: An International Journal 20(1), 86-105.

Davis, L. (2004). The effect of health risk on housing values: Evidence from a cancer cluster. American Economic Review 94(5), 1693-1704.

Davis, L. (2011). The effect of power plants on local housing values and rents. The Review of Economics and Statistics 93(4), 1391-1402.

De Pater, C. J. and S. Baisch (2011). Geomechanical study of bowland shale seismicity, synthesis report. Technical report, Cuadrilla Resources Ltd., Lancashire, U. K.

DECC (2013). Developing onshore shale gas and oil facts about 'fracking'. Technical report, DECC, London.

DECC (2014). Response to sunday times article on value of homes in areas of shale extraction. Technical report, DECC, London.

DECC (2015a). Digest of united kingdom energy statistics. Technical report, DECC, London.

DECC (2015b). Onshore oil and gas exploration in the uk: regulation and best practice. Technical report, DECC, London.

Delgado, M. S., T. Guilfoos, and A. Boslett (2016). The cost of unconventional gas extraction: A hedonic analysis. Resource and Energy Economics 46(C), 1-22.

Dröes, M. I. and H. R. Koster (2016). Renewable energy and negative externalities: The effect of wind turbines on house prices. Journal of Urban Economics 96, 121 - 141.

Ekeland, I., J. Heckman, and L. Nesheim (2004). Identification and estimation of hedonic models. Journal of Political Economy 112(S1), S60-S109.

Epple, D. (1987). Hedonic prices and implicit markets: Estimating demand and supply functions for differentiated products. Journal of Political Economy 95(1), 59-80.

Feyrer, J., E. Mansur, and B. Sacerdote (2015). Geographic dispersion of economic shocks: Evidence from the fracking revolution. NBER Working Papers 21624, National Bureau of Economic Research, Inc.

Fontenot, B. E., L. R. Hunt, Z. L. Hildenbrand, D. D. Carlton Jr., H. Oka, J. L. Walton, D. Hopkins, A. Osorio, B. Bjorndal, Q. H. Hu, and K. A. Schug (2013). An evaluation of water quality in private drinking water wells near natural gas extraction sites in the barnett shale formation. Environmental Science \& Technology 47(17), 10032-10040.

Gamper-Rabindran, S. and C. Timmins (2013). Does cleanup of hazardous waste sites raise housing values? evidence of spatially localized benefits. Journal of Environmental Economics and Management 65(3), 345-360. 
Gibbons, S. (2004). The costs of urban property crime*. The Economic Journal 114(499), F441-F463.

Gibbons, S. (2015). Gone with the wind: Valuing the visual impacts of wind turbines through house prices. Journal of Environmental Economics and Management 72(C), 177-196.

Gibbons, S., S. Machin, and O. Silva (2013). Valuing school quality using boundary discontinuities. Journal of Urban Economics 75(C), 15-28.

Gilman, J. B., B. M. Lerner, W. C. Kuster, and J. A. de Gouw (2013). Source signature of volatile organic compounds from oil and natural gas operations in northeastern colorado. Environmental Science \& Technology 47(3), 1297-1305.

Gobillon, L. and T. Magnac (2016). Regional policy evaluation: Interactive fixed effects and synthetic controls. The Review of Economics and Statistics 98(3), 535-551.

Gopalakrishnan, S. and H. Klaiber (2014). Is the shale energy boom a bust for nearby residents? evidence from housing values in pennsylvania. American Journal of Agricultural Economics 96(1), 43-66.

Green, C.A., P. S. and B. Baptie (2012). Preese hall shale gas fracturing: Review and recommendations for induced seismic mitigation. induced seismic mitigation report. Technical report.

Greenberg, M. and J. Hughes (1992). The impact of hazardous waste superfund sites on the value of houses sold in new jersey. The Annals of Regional Science 26(2), 147-53.

Greenstone, M. and J. Gallagher (2008). Does hazardous waste matter? evidence from the housing market and the superfund program. The Quarterly Journal of Economics 123(3), 951-1003.

Haninger, K., L. Ma, and C. Timmins (2014). The value of brownfield remediation. NBER Working Papers 20296, National Bureau of Economic Research, Inc.

Harrison, D. and D. L. Rubinfeld (1978). Hedonic housing prices and the demand for clean air. Journal of Environmental Economics and Management 5(1), 81-102.

Heckman, J., R. Matzkin, and L. Nesheim (2010). Nonparametric identification and estimation of nonadditive hedonic models. Econometrica 78(5), 1569-1591.

James, A. and J. James (2014). A canary near a gas well: Gas booms and housing market busts in colorado.

Keeler, J. T. S. (2015). The Global Impact of Unconventional Shale Gas Development: Economics, Policy and Interdependence, Volume 39 of Natural Resource Management and Policy, Chapter The Politics of Shale Gas and Anti-fracking Movements in France and the UK, pp. 43-74. New York and Heidelberg: Springer.

Kiel, K. and M. Williams (2007). The impact of superfund sites on local property values: Are all sites the same? Journal of Urban Economics 61(1), 170-192. 
Koster, H. R. and J. van Ommeren (2015). A shaky business: Natural gas extraction, earthquakes and house prices. European Economic Review 80(C), 120-139.

Leake, J. and E. Thomson (2014). Fracking digs deep hole in house values. Sunday Times 24. August 2014.

Leggett, C. G. and N. E. Bockstael (2000). Evidence of the effects of water quality on residential land prices. Journal of Environmental Economics and Management 39(2), 121-144.

Linden, L. and J. E. Rockoff (2008). Estimates of the impact of crime risk on property values from megan's laws. American Economic Review 98(3), 1103-27.

Linn, J. (2013). The effect of voluntary brownfields programs on nearby property values: Evidence from illinois. Journal of Urban Economics 78, 1-18.

Mendelsohn, R. (1985). Identifying structural equations with single market data. The Review of Economics and Statistics 67(3), 525-29.

Muehlenbachs, L. and A. Krupnick (2014). Infographic: Shale gas development linked to traffic accidents in pennsylvania. Resources 185.

Muehlenbachs, L., E. Spiller, and C. Timmins (2015). The housing market impacts of shale gas development. American Economic Review 105(12), 3633-59.

Olmstead, S. M., L. A. Muehlenbachs, J.-S. Shih, Z. Chu, and A. J. Krupnick (2013). Shale gas development impacts on surface water quality in pennsylvania. Proceedings of the National Academy of Sciences 110(13), 4962-4967.

Palmquist, R. B., F. M. Roka, and T. Vukina (1997). Hog operations, environmental effects, and residential property values. Land Economics 73(1), 114-124.

Poor, P. J., K. L. Pessagno, and R. W. Paul (2007). Exploring the hedonic value of ambient water quality: A local watershed-based study. Ecological Economics 60(4), 797-806.

Pope, J. (2008a). Fear of crime and housing prices: Household reactions to sex offender registries. Journal of Urban Economics 64(3), 601-614.

Pope, J. C. (2008b). Buyer information and the hedonic: The impact of a seller disclosure on the implicit price for airport noise. Journal of Urban Economics 63(2), 498 - 516.

Ronald G. Ridker, J. A. H. (1967). The determinants of residential property values with special reference to air pollution. The Review of Economics and Statistics 49(2), 246-257.

Rosen, S. (1974). Hedonic prices and implicit markets: Product differentiation in pure competition. Journal of Political Economy 82(1), 34-55. 
Roy, A., P. A. and A. Robinson (2014). Air pollutant emissions from the development, production, and processing of marcellus shale natural gas. Journal of the Air $\mathcal{E}$ Waste Management Association 64(1), 19-37.

Throupe, R., R. Simons, and X. Mao (2013). A review of hydro fracking and its potential effects on real estate. Journal of Real Estate Literature 21(2), 205-232.

UKOOG (2013). Community engagement charter oil and gas from unconventional reservoirs. Technical report, UKOOG.

Walsh, P., J. W. Milon, and D. O. Scrogin (2011). The spatial extent of water quality benefits in urban housing markets. Land Economics 87(4).

Warner, N. R., C. A. Christie, R. B. Jackson, and A. Vengosh (2013). Impacts of shale gas wastewater disposal on water quality in western pennsylvania. Environmental Science $\mathcal{E}$ Technology 47(20), 11849-11857.

Yinger, J. (2015). Hedonic markets and sorting equilibria: Bid-function envelopes for public services and neighborhood amenities. Journal of Urban Economics 86(C), 9-25.

Zabel, J. and D. Guignet (2012). A hedonic analysis of the impact of lust sites on house prices. Resource and Energy Economics 34(4), 549-564. 


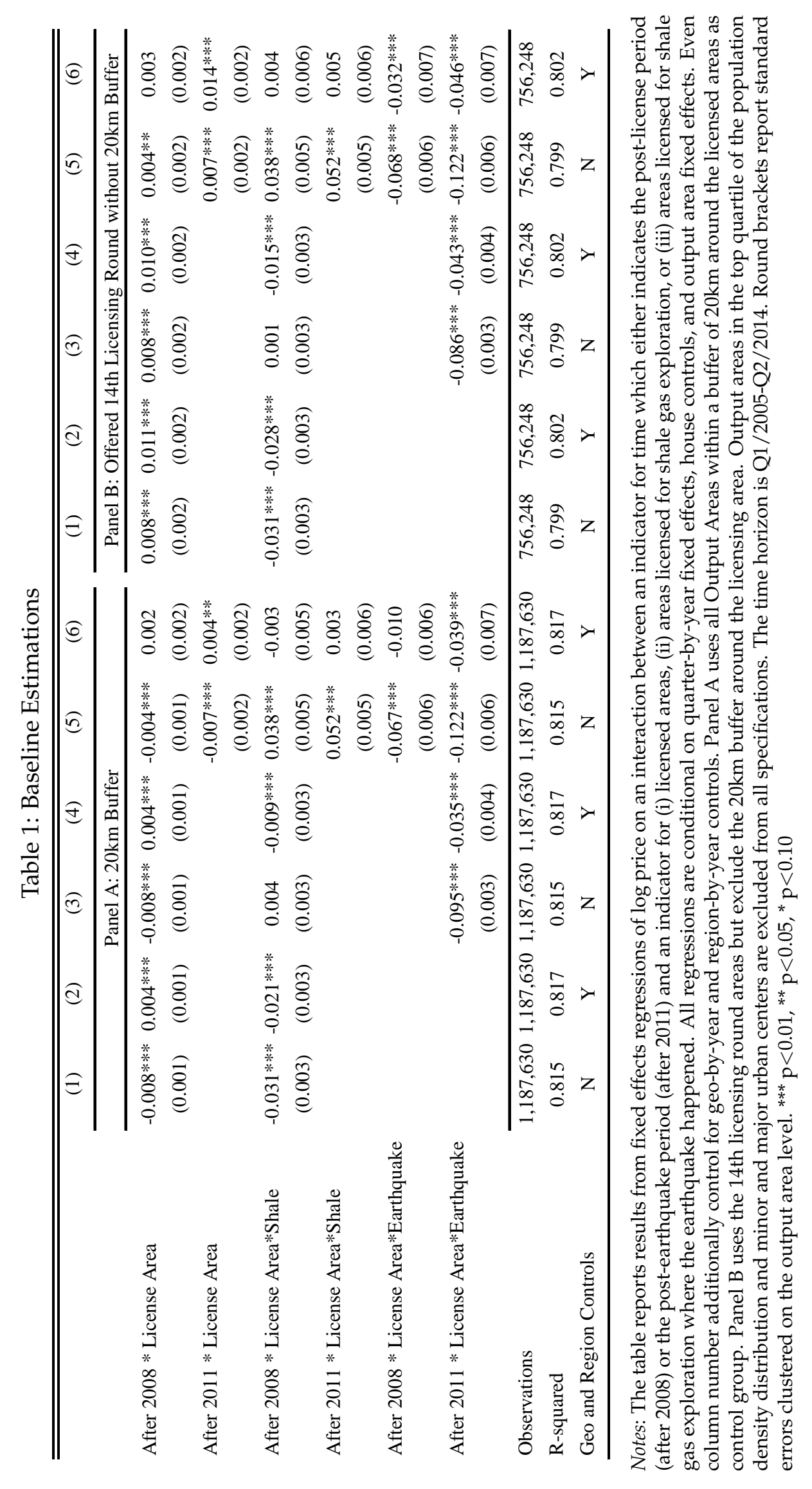




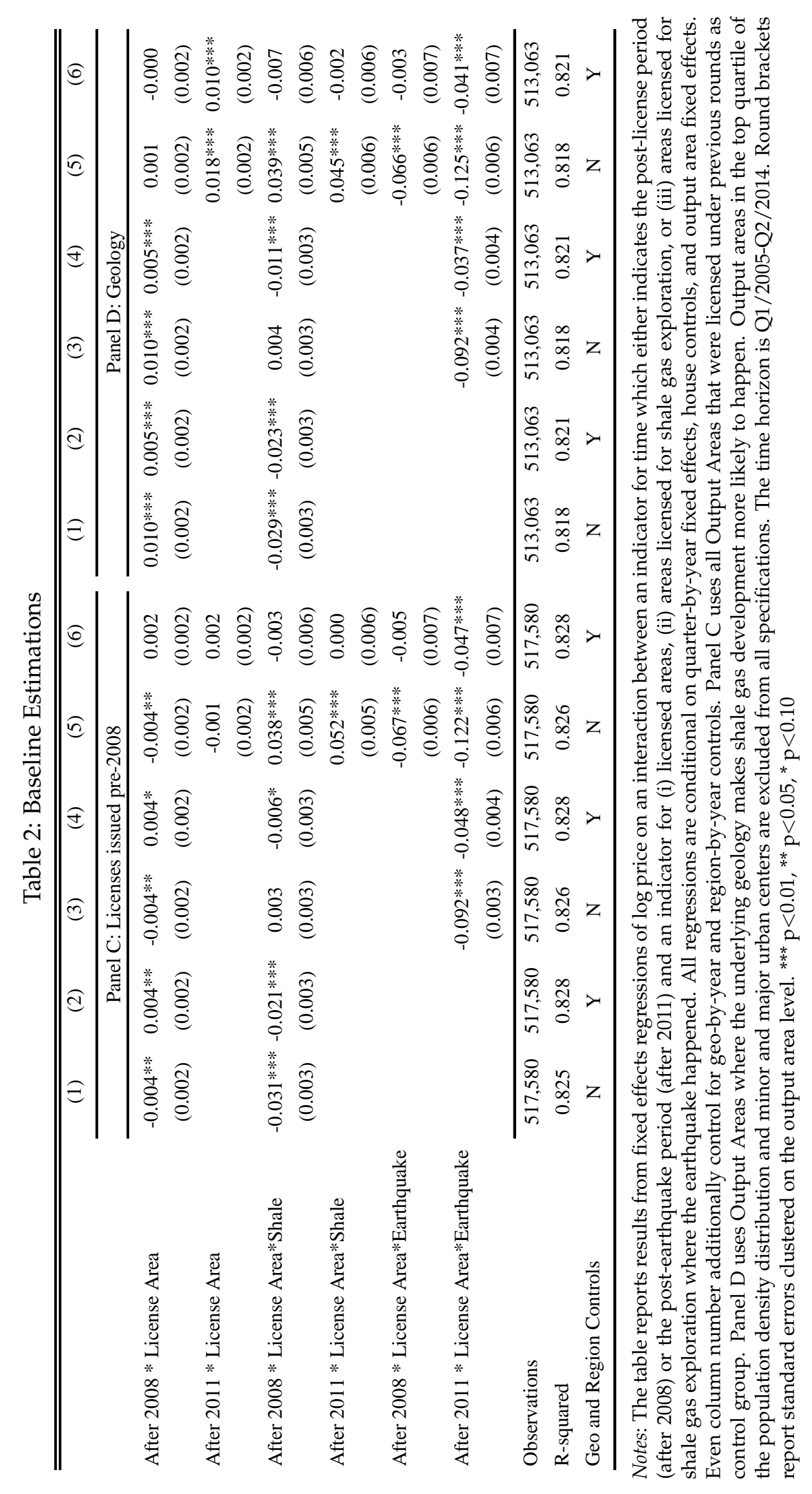




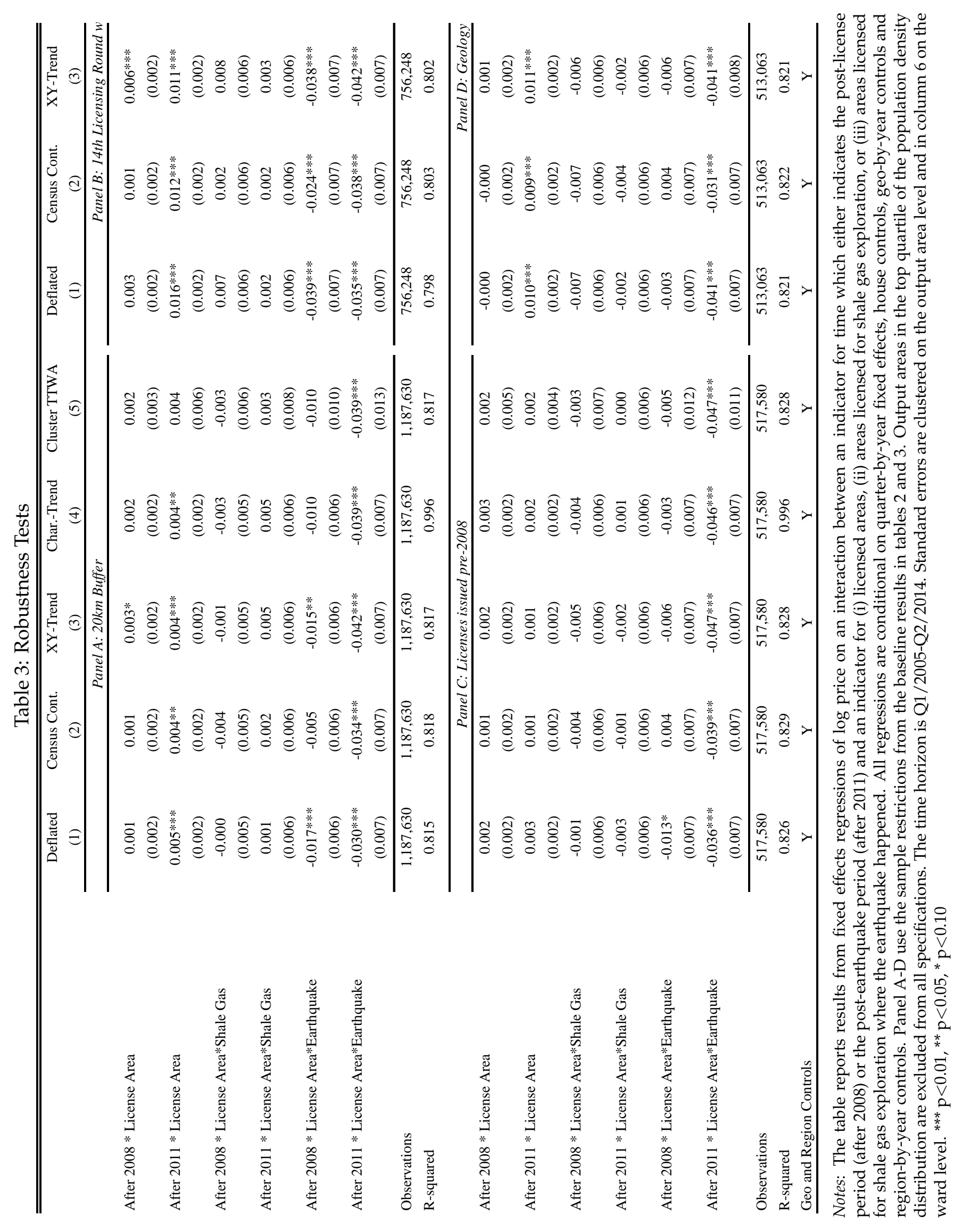


Table 4: Interactive Fixed Effects

\begin{tabular}{lcccc}
\hline \hline & $(1)$ & $(2)$ & $(3)$ & $(4)$ \\
& $(\mathrm{A})$ & $(\mathrm{B})$ & $(\mathrm{C})$ & $(\mathrm{D})$ \\
\cline { 2 - 5 } & & & & 0.000 \\
After $2008 *$ License Area & 0.002 & 0.000 & $0.005 *$ & $(0.003)$ \\
& $(0.002)$ & $(0.003)$ & $(0.003)$ & $0.011 * * *$ \\
After 2011* License Area & $0.006 * * *$ & $0.013 * * *$ & $0.005 * *$ & $(0.003)$ \\
& $(0.002)$ & $(0.003)$ & $(0.003)$ & -0.006 \\
After 2008* License Area*Shale Gas & -0.002 & 0.007 & 0.003 & $(0.006)$ \\
After 2011* License Area*Shale Gas & $(0.006)$ & $(0.007)$ & $(0.007)$ & 0.003 \\
After 2008* License Area*Earthquake & 0.009 & 0.002 & 0.002 & $(0.007)$ \\
After 2011* License Area*Earthquake & $(0.008)$ & $(0.008)$ & $(0.007)$ & 0.002 \\
R-squared & -0.004 & $-0.018 * *$ & -0.002 & $(0.008)$ \\
Geo and Region Controls & $(0.008)$ & $(0.009)$ & $(0.009)$ & $-0.039 * * *$ \\
\hline
\end{tabular}

Notes: The table reports results from interactive fixed effects regressions of different house characteristics on an interaction between an indicator for time which either indicates the post-license period (after 2008) or the post-earthquake period (after 2011) and an indicator for (i) licensed areas, (ii) areas licensed for shale gas exploration, or (iii) areas licensed for shale gas exploration where the earthquake happened. All regressions are conditional on quarter-by-year fixed effects, house controls, geo-by-year controls, region-by-year controls and two factors that flexibly absorb output area-specific shocks. Sample (A) uses all output areas within a buffer of $20 \mathrm{~km}$ around the licensed areas as control group. Sample (B) uses the 14 th licensing round areas but exclude the $20 \mathrm{~km}$ buffer around the licensing area. Sample (C) uses all Output Areas that were licensed under previous rounds as control group. Sample (D) restricts the sample to all output areas which the British Geological Survey classifies as promising for shale gas development. Output areas in the top quartile of the population density distribution are excluded from all specifications. The time horizon is Q1/2005-Q2/2014. Standard errors are clustered on the output area level. ${ }^{* *} \mathrm{p}<0.01,{ }^{* *} \mathrm{p}<0.05,{ }^{*} \mathrm{p}<0.10$ 


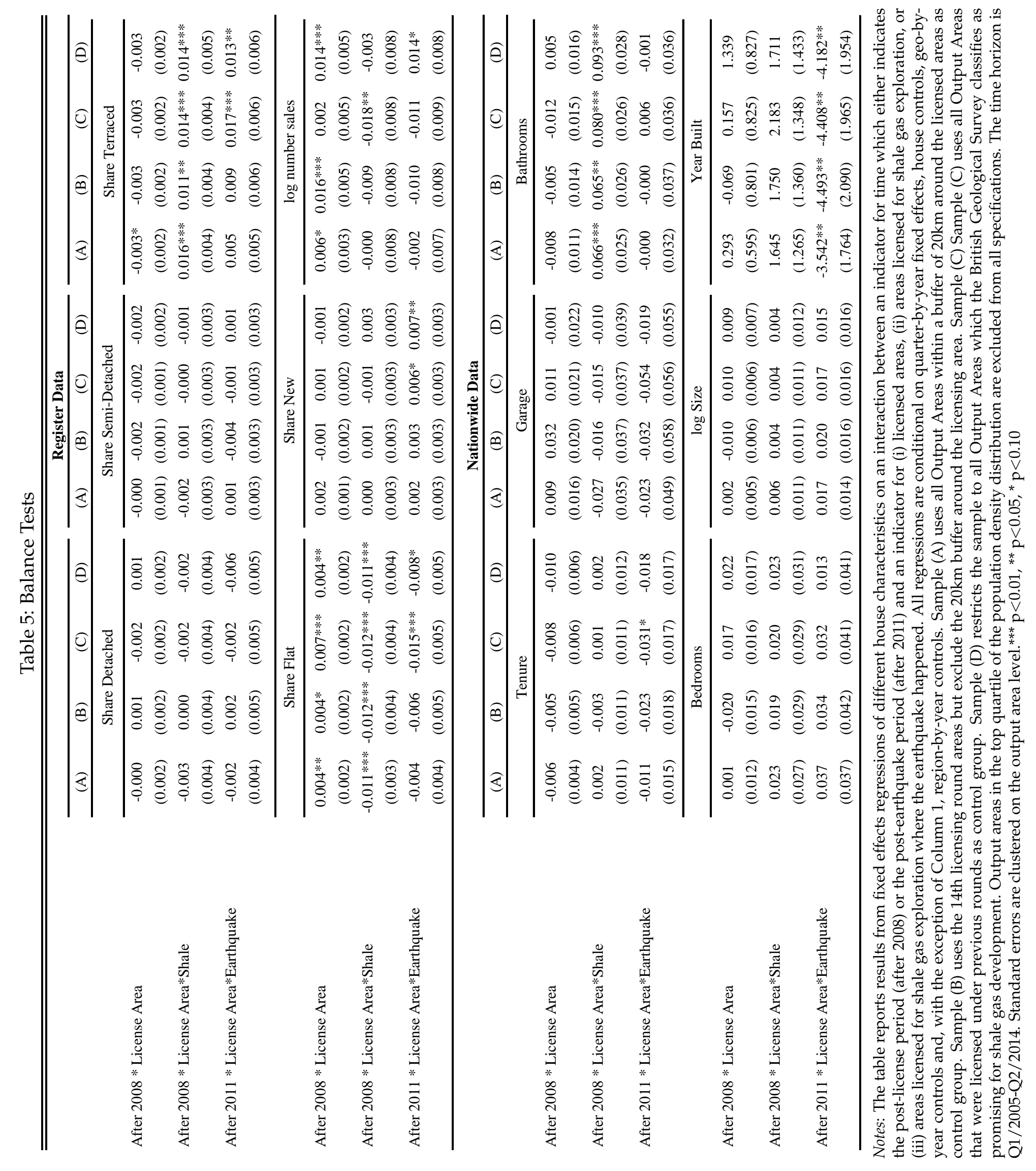




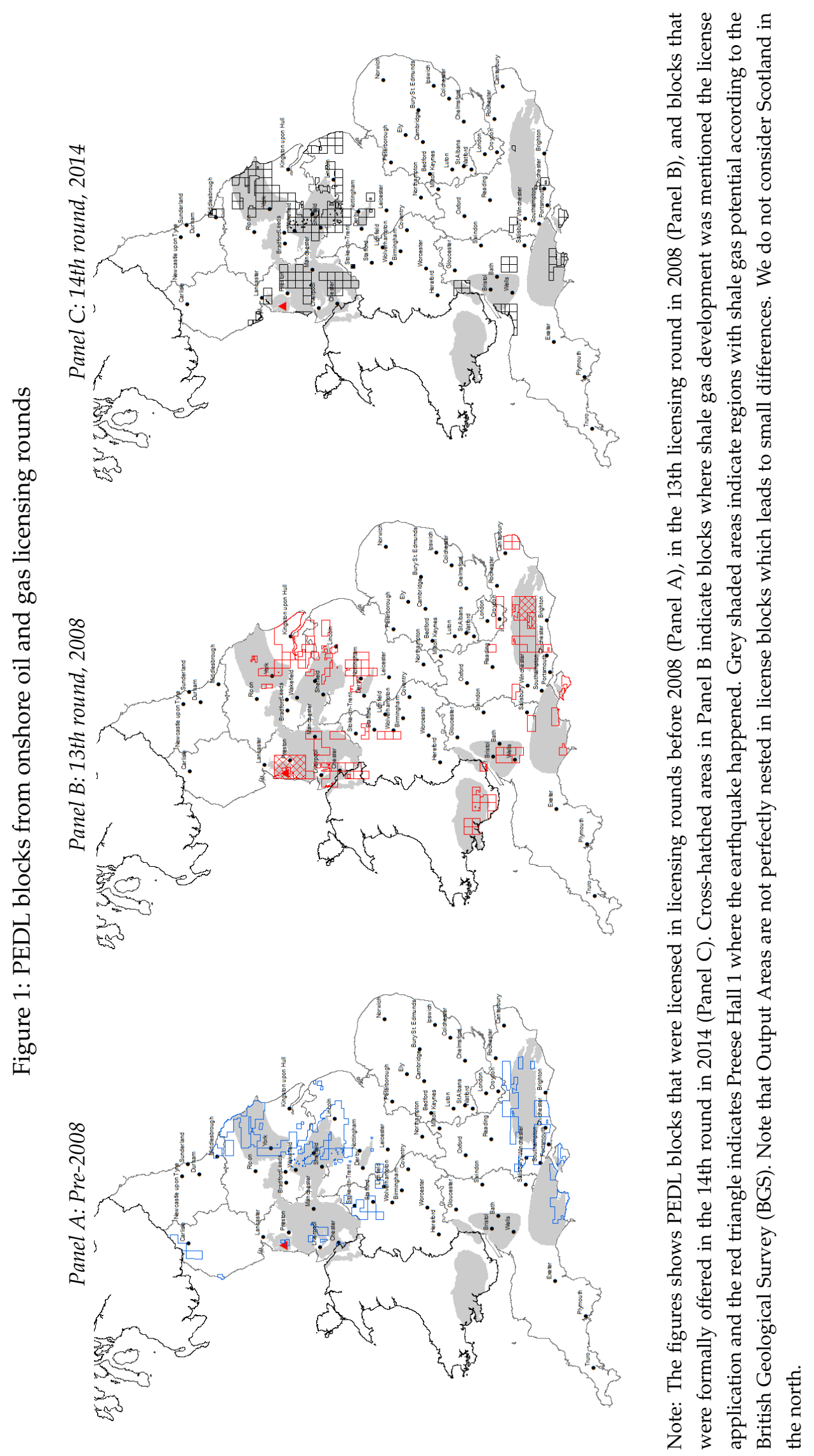




\section{Figure 2: Control Group Specifications}
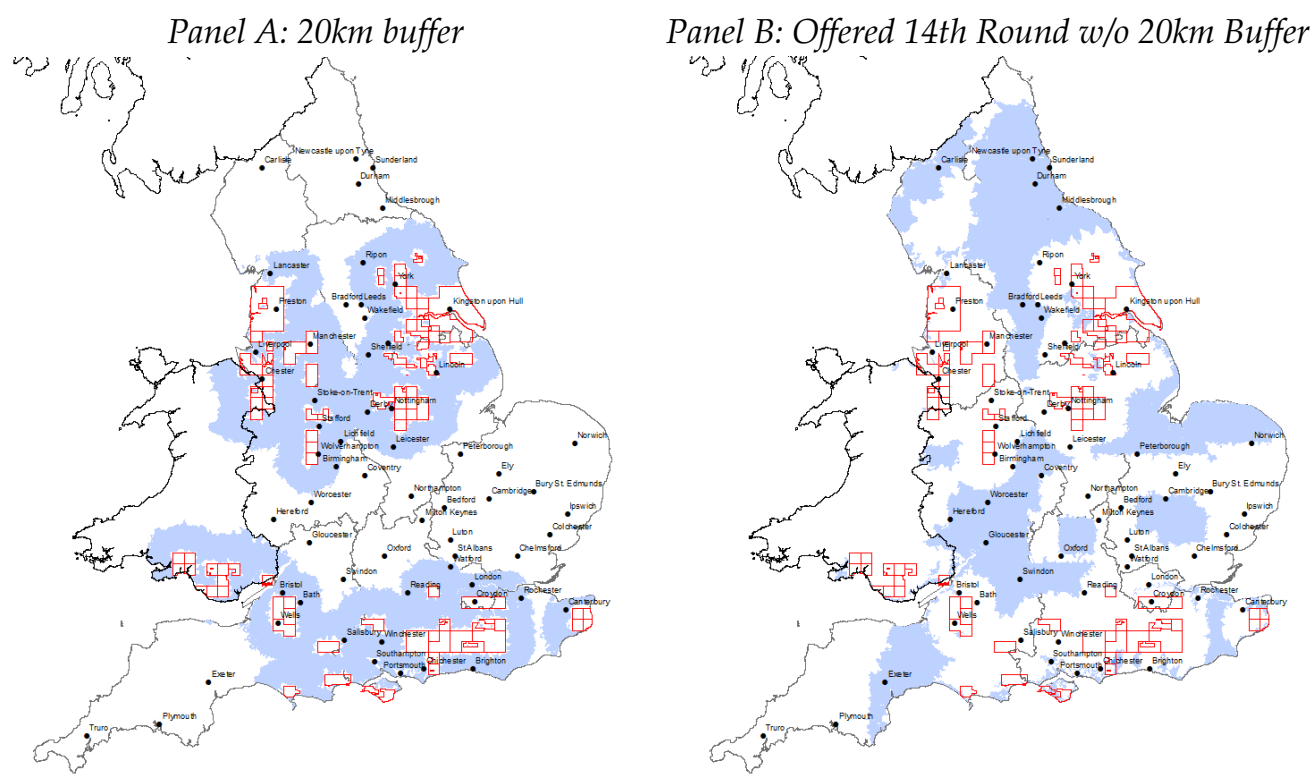

Panel C: Licenses issued pre-2008
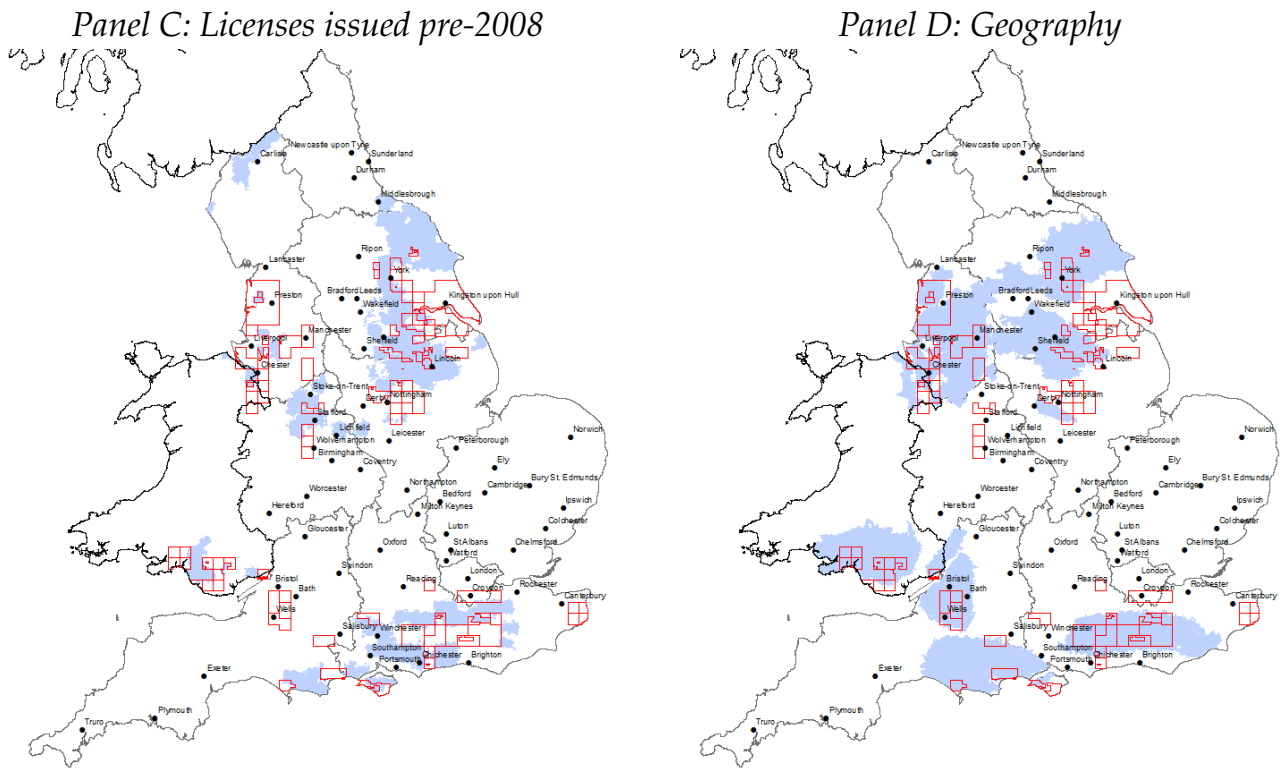

Note: The Figure shows four different control group definitions. The red outlines indicate blocks that were licensed under the 13th round in 2008 and the blue shaded areas mark the respective Output Areas that comprise the control group. 
Figure 3: Estimated Effects

Panel A: 20km buffer

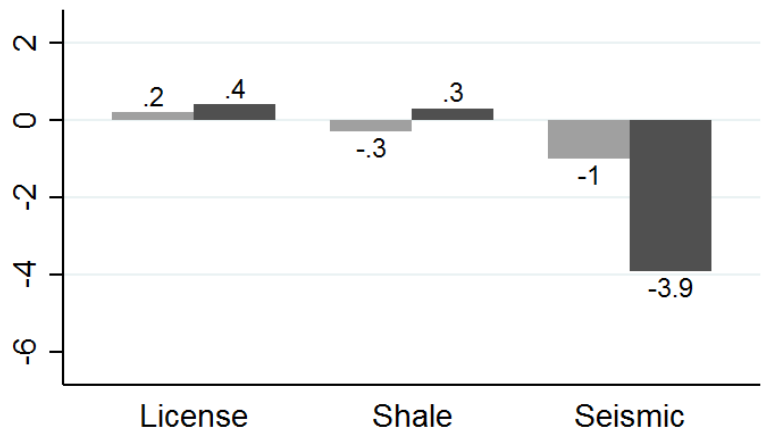

Panel C: Licenses issued pre-2008

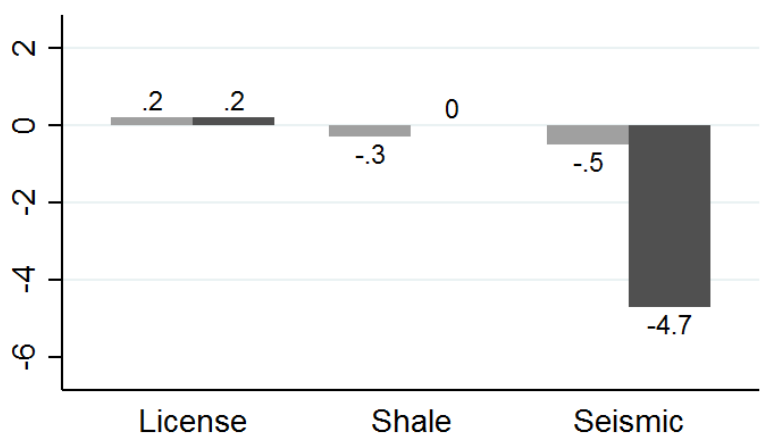

Panel B: W/o 20km buffer

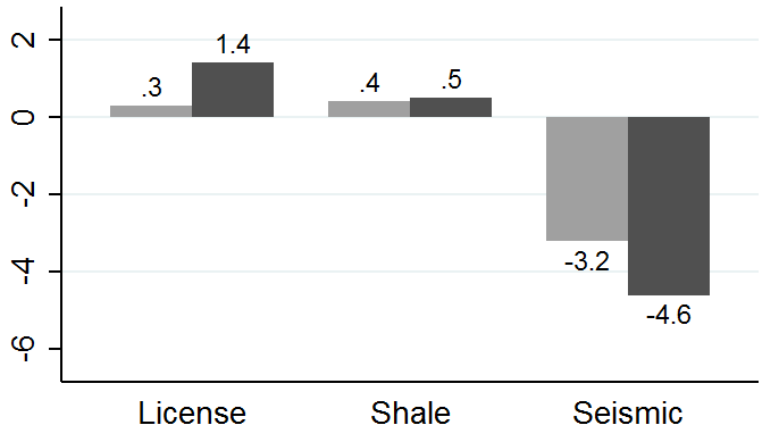

Panel D: Geology

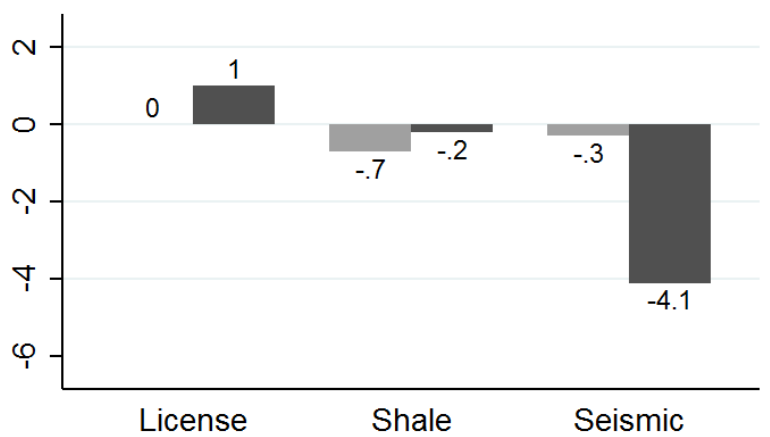

Note: The Figure shows the estimated effects for the coefficients in Tables 1 and 2, Column 6. Light grey bars refer to interactions with an after-2008 dummy and dark grey bars to interactions with the after-2011 dummy. The three areas are licensed areas, licensed areas where shale gas development was mentioned, and finally the one region where fracking activities caused two earthquakes (seismic). 
Figure 4: Distance Rings around Preese Hall 1

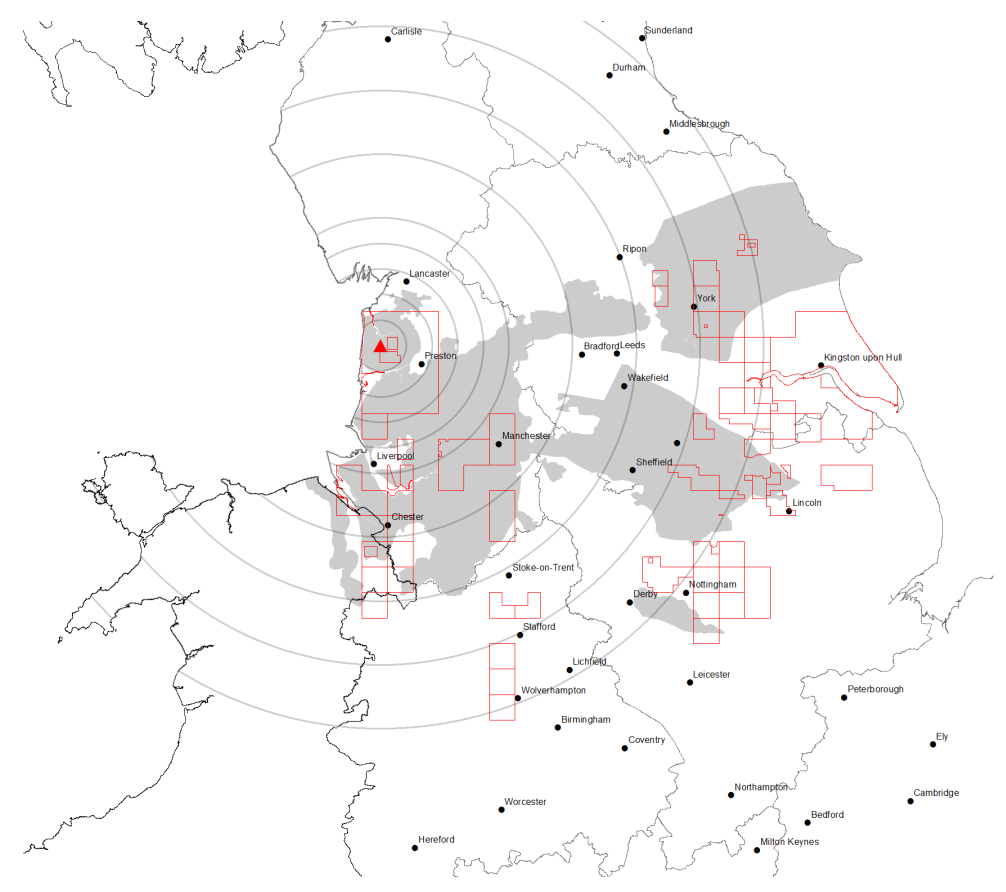

Note: The figure shows Preese Hall well (red triangle) and 7 distance rings around it. The rings are at 10, 20, 30, 40, 50,75 , and $100 \mathrm{~km}$ from the well. The red blocks indicate areas licensed under the 13th licensing round in 2008 and the grey areas indicate a geology that is promising for shale gas.

\section{Figure 5: Distance Decay Estimations}

Panel A: DiD

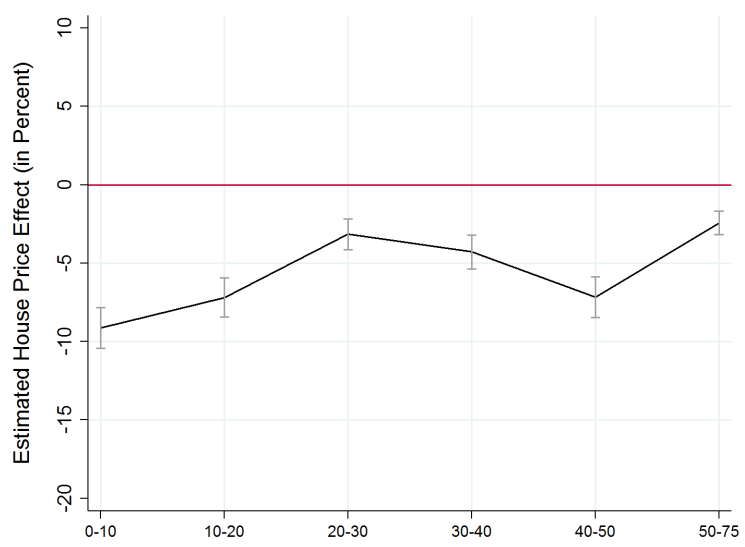

Panel A: DDD

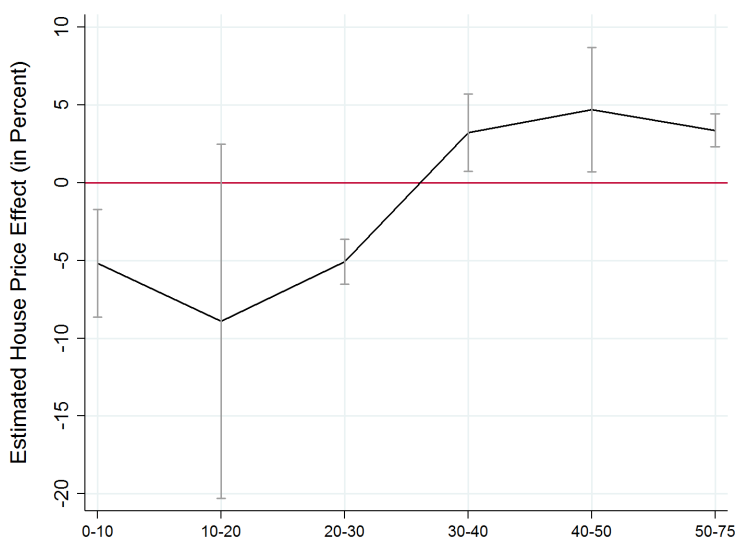

Note: The figure shows the estimated coefficients $\tau_{r}$ from equation 5 (Panel A) and $\phi_{r}$ from equation 6 (Panel B) enclosed by $95 \%$-confidence intervals. The omitted category is the bin $(75,100]$. 
Figure 6: Placebo Locations
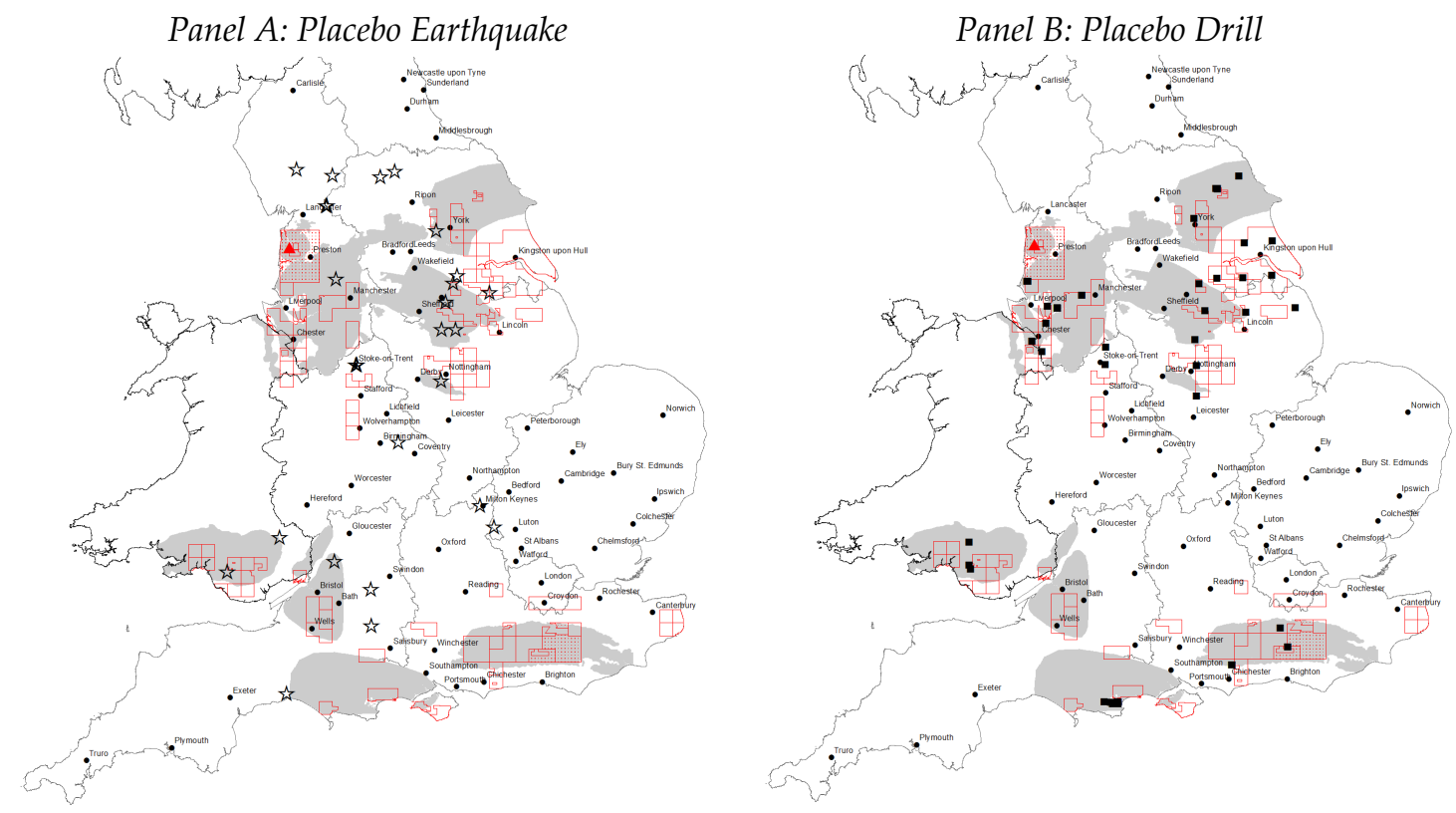

Notes: The grey areas mark areas with geology that is suitable for shale gas development and the red outlines indicate areas that were licensed in 2008. In Panel A, stars indicate areas that experienced an earthquake of magnitude 1.52.3 between 2010/Q1 and 2011/Q1. In Panel B, squares indicate wells that were drilled for conventional oil and gas development between 2011/Q1 and 2015/Q4.

Figure 7: Distance decay around placebo locations

Panel A: Placebo Earthquakes

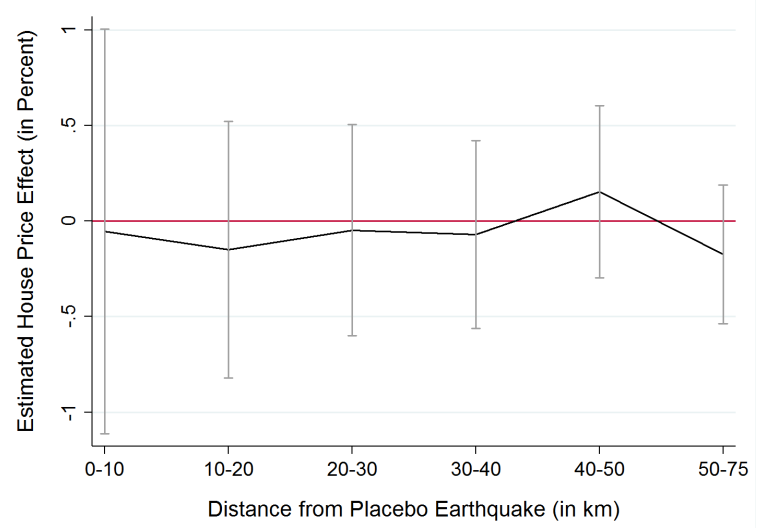

Panel B: Placebo Drills

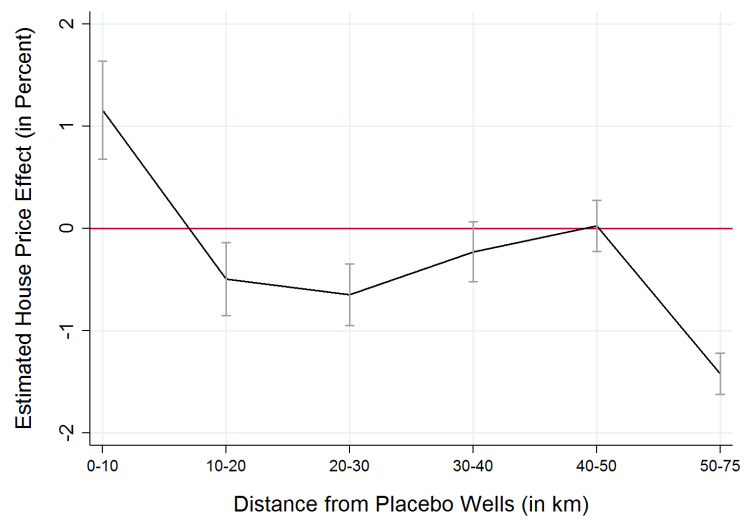

Note: The figure shows the estimated coefficients $\tau_{r}$ from equation 5 for placebo earthquake and placebo drill locations enclosed by $95 \%$-confidence intervals. The omitted category is the bin $(75,100]$. 
Figure 8: Event study
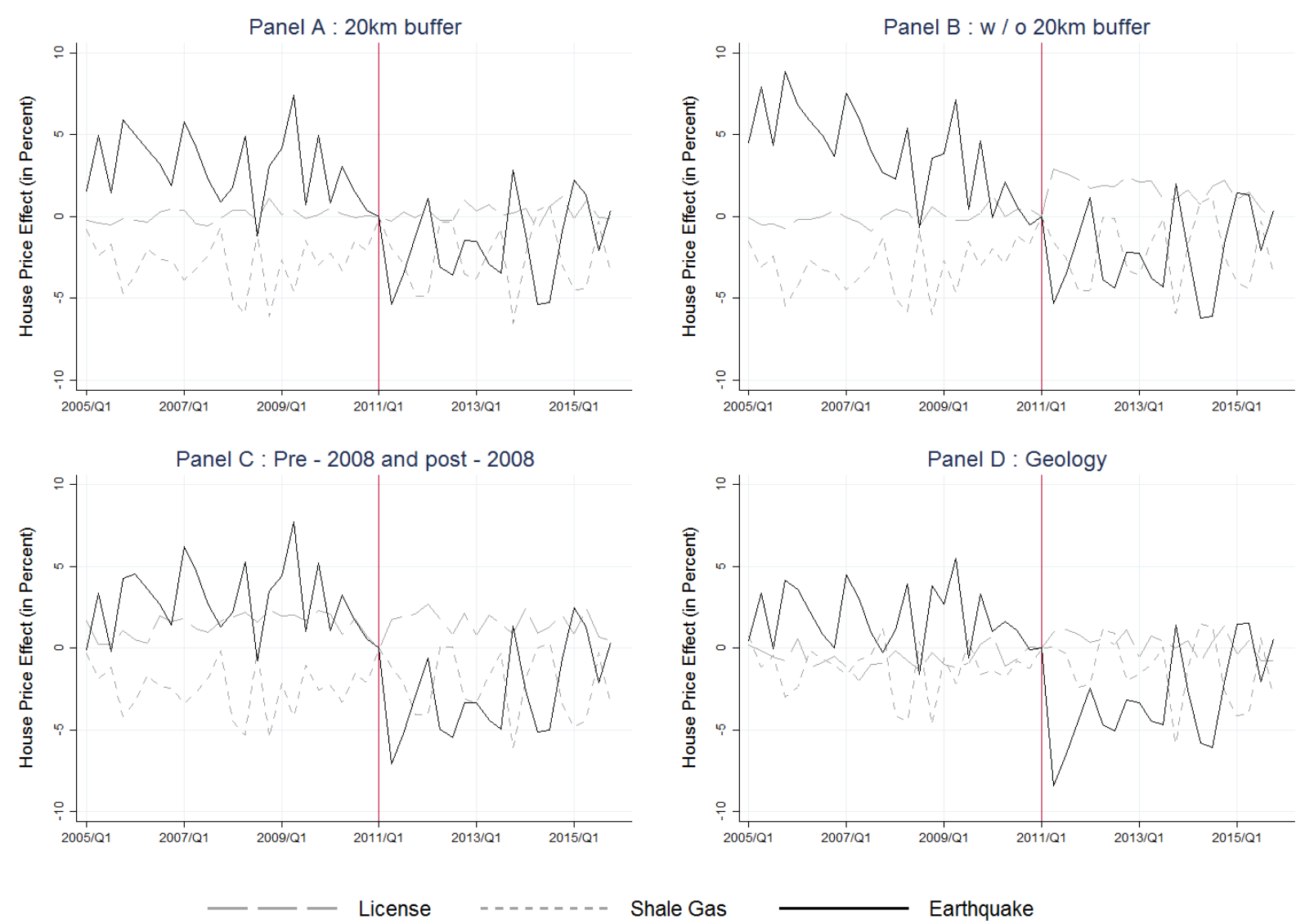

Note: The figure shows the estimated effects of the event time indicators $\omega_{t}$ for the licensed areas (long-dashed line), $\pi_{t}$ for the licensed areas where shale gas development was mentioned (short-dashed line), and $\eta_{t}$ for the earthquake region (solid line). The omitted period is 2011/Q1. 
Figure A1: Correlation between earthquake and injected volume

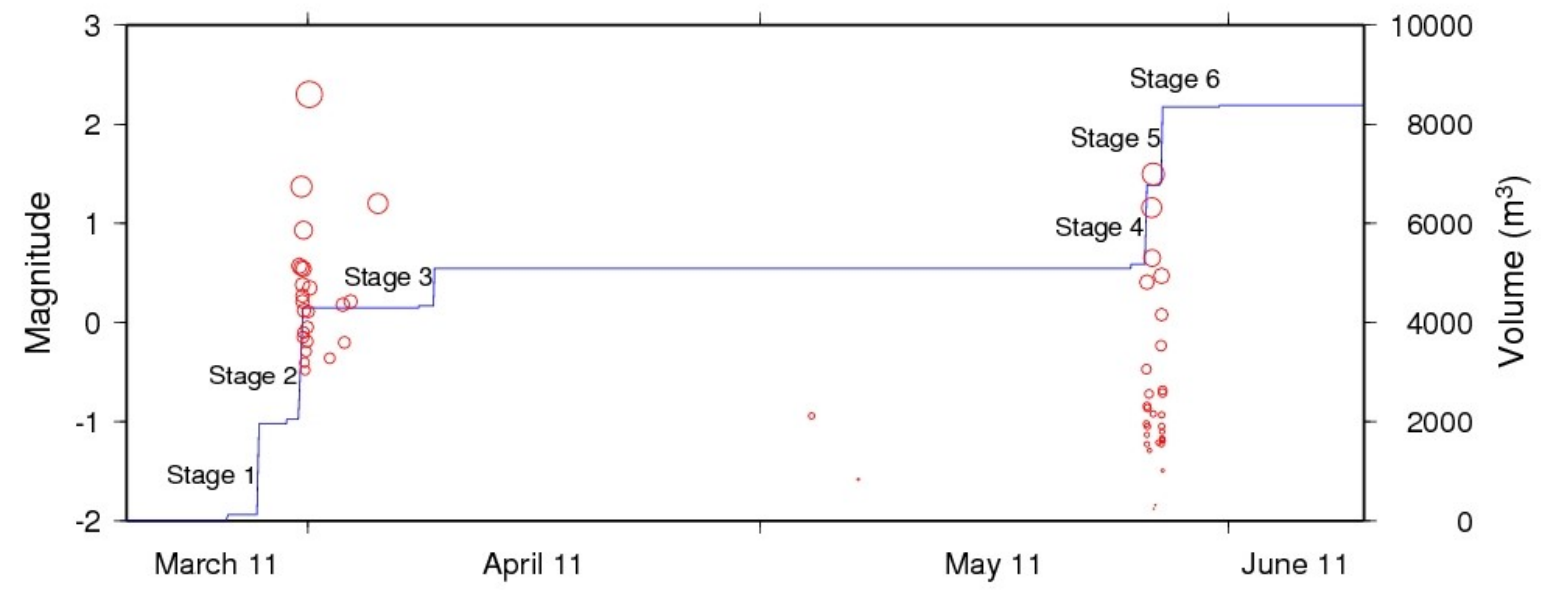

Note: The Figure shows the correlation between the injected volume (blue line) during hydraulic fracturing between March and June at Preese Hall 1 and the corresponding seismic activity (red circles). Source BGS: http://www.earthquakes.bgs.ac.uk/research/BlackpoolEarthquakes.html 
Table A1: Descriptive Statistics

\begin{tabular}{|c|c|c|c|c|c|c|c|c|c|c|c|c|c|c|}
\hline \multirow[b]{4}{*}{ Panel A: 2005-2014 } & \multicolumn{6}{|c|}{ Treatment } & \multicolumn{8}{|c|}{ Control } \\
\hline & \multicolumn{2}{|c|}{ License 2008} & \multicolumn{2}{|c|}{ Shalegas } & \multicolumn{2}{|c|}{ Earthquake } & \multicolumn{2}{|c|}{ Sample A } & \multicolumn{2}{|c|}{ Sample B } & \multicolumn{2}{|c|}{ Sample C } & \multicolumn{2}{|c|}{ Sample D } \\
\hline & Mean & s.d. & Mean & s.d. & Mean & s.d. & Mean & s.d. & Mean & s.d. & Mean & s.d. & Mean & s.d. \\
\hline & & & & & & & & & & & & & & \\
\hline Log price & 12.08 & 0.55 & 12.08 & 0.52 & 11.92 & 0.45 & 12.13 & 0.52 & 12.07 & 0.52 & 12.09 & 0.56 & 12.04 & 0.56 \\
\hline New built & 0.03 & 0.15 & 0.03 & 0.14 & 0.02 & 0.13 & 0.03 & 0.15 & 0.04 & 0.16 & 0.04 & 0.16 & 0.03 & 0.15 \\
\hline Detached house & 0.32 & 0.42 & 0.29 & 0.41 & 0.25 & 0.39 & 0.32 & 0.42 & 0.32 & 0.42 & 0.33 & 0.42 & 0.31 & 0.42 \\
\hline Semi-detached house & 0.11 & 0.28 & 0.12 & 0.29 & 0.10 & 0.28 & 0.10 & 0.27 & 0.08 & 0.24 & 0.10 & 0.27 & 0.08 & 0.24 \\
\hline Terraced house & 0.34 & 0.42 & 0.40 & 0.44 & 0.45 & 0.45 & 0.33 & 0.42 & 0.33 & 0.41 & 0.35 & 0.42 & 0.33 & 0.42 \\
\hline Flat/Maisonette & 0.23 & 0.38 & 0.19 & 0.35 & 0.20 & 0.36 & 0.25 & 0.38 & 0.27 & 0.39 & 0.22 & 0.37 & 0.27 & 0.40 \\
\hline Freehold & 0.84 & 0.33 & 0.77 & 0.38 & 0.75 & 0.40 & 0.87 & 0.30 & 0.89 & 0.28 & 0.88 & 0.29 & 0.86 & 0.32 \\
\hline Number of sales & 1.99 & 2.11 & 1.99 & 2.17 & 1.94 & 2.20 & 2.03 & 2.21 & 2.05 & 2.49 & 2.01 & 2.05 & 1.99 & 2.05 \\
\hline \multicolumn{15}{|l|}{ Panel B: $2005-2008$} \\
\hline Log price & 12.07 & 0.53 & 12.10 & 0.49 & 11.96 & 0.44 & 12.12 & 0.50 & 12.06 & 0.50 & 12.08 & 0.53 & 12.04 & 0.54 \\
\hline New built & 0.04 & 0.16 & 0.03 & 0.15 & 0.03 & 0.14 & 0.04 & 0.16 & 0.04 & 0.16 & 0.04 & 0.17 & 0.04 & 0.16 \\
\hline Detached house & 0.30 & 0.41 & 0.27 & 0.39 & 0.24 & 0.38 & 0.31 & 0.41 & 0.31 & 0.40 & 0.31 & 0.41 & 0.30 & 0.40 \\
\hline Semi-detached house & 0.11 & 0.27 & 0.12 & 0.29 & 0.11 & 0.27 & 0.10 & 0.26 & 0.09 & 0.24 & 0.10 & 0.26 & 0.08 & 0.24 \\
\hline Terraced house & 0.34 & 0.41 & 0.40 & 0.42 & 0.44 & 0.43 & 0.34 & 0.40 & 0.33 & 0.40 & 0.35 & 0.41 & 0.34 & 0.41 \\
\hline Flat/Maisonette & 0.24 & 0.38 & 0.21 & 0.35 & 0.21 & 0.36 & 0.25 & 0.38 & 0.28 & 0.39 & 0.23 & 0.37 & 0.29 & 0.39 \\
\hline Freehold & 0.84 & 0.33 & 0.77 & 0.38 & 0.75 & 0.39 & 0.86 & 0.30 & 0.89 & 0.28 & 0.88 & 0.29 & 0.85 & 0.31 \\
\hline Number of sales & 2.31 & 2.65 & 2.32 & 2.80 & 2.28 & 2.84 & 2.36 & 2.82 & 2.38 & 3.21 & 2.33 & 2.59 & 2.31 & 2.61 \\
\hline \multicolumn{15}{|l|}{ Panel C: $2008-2011$} \\
\hline Log price & 12.07 & 0.56 & 12.07 & 0.53 & 11.91 & 0.46 & 12.12 & 0.53 & 12.06 & 0.52 & 12.09 & 0.56 & 12.04 & 0.57 \\
\hline New built & 0.04 & 0.17 & 0.03 & 0.16 & 0.03 & 0.15 & 0.04 & 0.17 & 0.04 & 0.18 & 0.04 & 0.18 & 0.04 & 0.17 \\
\hline Detached house & 0.33 & 0.43 & 0.29 & 0.42 & 0.26 & 0.40 & 0.33 & 0.43 & 0.33 & 0.43 & 0.34 & 0.43 & 0.32 & 0.43 \\
\hline Semi-detached house & 0.11 & 0.29 & 0.12 & 0.30 & 0.11 & 0.29 & 0.10 & 0.27 & 0.08 & 0.25 & 0.10 & 0.28 & 0.08 & 0.25 \\
\hline Terraced house & 0.34 & 0.43 & 0.41 & 0.45 & 0.45 & 0.46 & 0.33 & 0.43 & 0.33 & 0.42 & 0.34 & 0.43 & 0.33 & 0.43 \\
\hline Flat/Maisonette & 0.22 & 0.38 & 0.18 & 0.35 & 0.18 & 0.36 & 0.24 & 0.39 & 0.25 & 0.40 & 0.21 & 0.37 & 0.26 & 0.40 \\
\hline Freehold & 0.84 & 0.34 & 0.77 & 0.39 & 0.75 & 0.41 & 0.87 & 0.31 & 0.89 & 0.28 & 0.88 & 0.30 & 0.86 & 0.33 \\
\hline Number of sales & 1.75 & 1.81 & 1.72 & 1.68 & 1.67 & 1.75 & 1.78 & 1.81 & 1.80 & 2.00 & 1.78 & 1.68 & 1.74 & 1.66 \\
\hline \multicolumn{15}{|l|}{ Panel D: 2011-2014 } \\
\hline Log price & 12.09 & 0.58 & 12.07 & 0.56 & 11.88 & 0.47 & 12.15 & 0.55 & 12.08 & 0.54 & 12.11 & 0.58 & 12.05 & 0.58 \\
\hline New built & 0.02 & 0.12 & 0.02 & 0.11 & 0.01 & 0.10 & 0.02 & 0.12 & 0.02 & 0.12 & 0.02 & 0.12 & 0.02 & 0.12 \\
\hline Detached house & 0.33 & 0.43 & 0.30 & 0.42 & 0.27 & 0.40 & 0.33 & 0.43 & 0.34 & 0.43 & 0.35 & 0.43 & 0.33 & 0.43 \\
\hline Semi-detached house & 0.10 & 0.28 & 0.12 & 0.29 & 0.10 & 0.28 & 0.10 & 0.27 & 0.08 & 0.24 & 0.10 & 0.27 & 0.08 & 0.24 \\
\hline Terraced house & 0.33 & 0.43 & 0.40 & 0.45 & 0.45 & 0.46 & 0.32 & 0.42 & 0.32 & 0.42 & 0.34 & 0.43 & 0.33 & 0.42 \\
\hline Flat/Maisonette & 0.23 & 0.38 & 0.18 & 0.35 & 0.18 & 0.36 & 0.24 & 0.39 & 0.26 & 0.40 & 0.22 & 0.37 & 0.27 & 0.40 \\
\hline Freehold & 0.85 & 0.33 & 0.78 & 0.38 & 0.76 & 0.40 & 0.88 & 0.30 & 0.90 & 0.27 & 0.88 & 0.29 & 0.86 & 0.31 \\
\hline Number of sales & 1.76 & 1.28 & 1.76 & 1.30 & 1.68 & 1.20 & 1.80 & 1.35 & 1.81 & 1.49 & 1.78 & 1.30 & 1.75 & 1.28 \\
\hline
\end{tabular}

Notes: Among the control groups, Sample (A) uses all Output Areas within a buffer of 20km around the licensed areas as control group; Sample (B) uses the 14th licensing round areas but exclude the $20 \mathrm{~km}$ buffer around the licensing area; Sample (C) uses all Output Areas that were licensed under previous rounds as control group; Sample (D) restricts the sample to all Output Areas which the British Geological Survey classifies as promising for shale gas development. Output areas in the top quartile of the population density distribution are excluded from all specifications. The time horizon is Q1/2005-Q2/2014. 


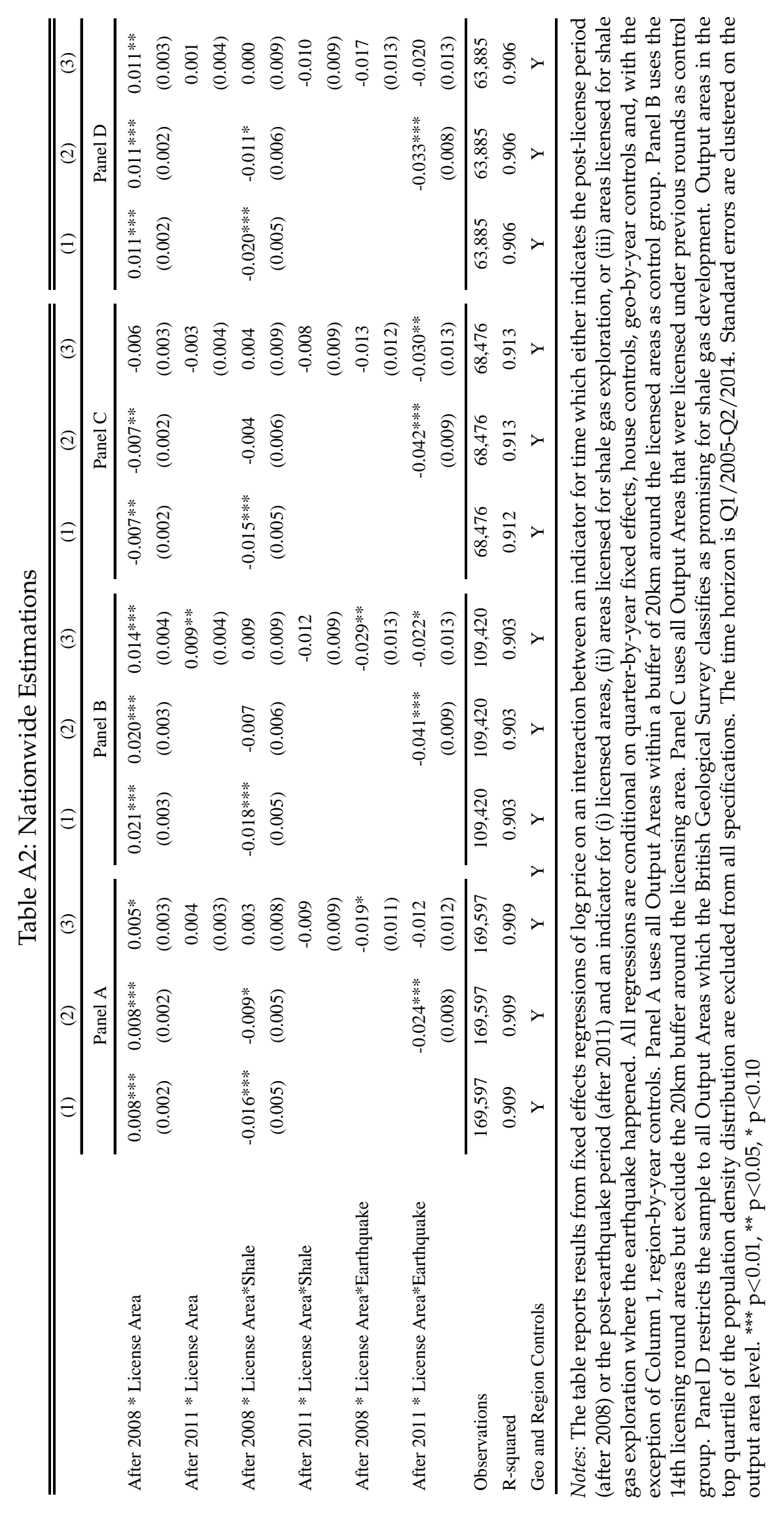


Table A3: Distance Decay Effect

\begin{tabular}{|c|c|c|c|c|}
\hline & $\begin{array}{l}\mathrm{DD} \\
\text { (1) }\end{array}$ & $\begin{array}{l}\text { DDD } \\
(2)\end{array}$ & $\begin{array}{c}\text { Placebo Seismic } \\
\text { (3) }\end{array}$ & $\begin{array}{c}\text { Placebo Well } \\
\text { (4) }\end{array}$ \\
\hline After $2011 * \mathrm{I}(0<$ dist $<=10)$ & $\begin{array}{c}-0.091 \text { **** } \\
(0.007)\end{array}$ & $\begin{array}{l}-0.032^{*} \\
(0.017)\end{array}$ & $\begin{array}{l}-0.001 \\
(0.005)\end{array}$ & $\begin{array}{c}0.012^{* * * *} \\
(0.002)\end{array}$ \\
\hline After $2011 * \mathrm{I}(10<$ dist $<=20)$ & $\begin{array}{c}-0.072 * * * * \\
(0.006)\end{array}$ & $\begin{array}{c}0.026 \\
(0.058)\end{array}$ & $\begin{array}{l}-0.001 \\
(0.003)\end{array}$ & $\begin{array}{c}-0.005^{* * *} \\
(0.002)\end{array}$ \\
\hline After $2011 * \mathrm{I}(20<$ dist< $<=30)$ & $\begin{array}{c}-0.031 * * * \\
(0.005)\end{array}$ & $\begin{array}{c}0.010 \\
(0.007)\end{array}$ & $\begin{array}{l}-0.000 \\
(0.003)\end{array}$ & $\begin{array}{c}-0.007 * * * \\
(0.002)\end{array}$ \\
\hline After $2011 * \mathrm{I}(30<$ dist $<=40)$ & $\begin{array}{c}-0.043 * * * \\
(0.006)\end{array}$ & $\begin{array}{c}-0.041^{* * * *} \\
(0.006)\end{array}$ & $\begin{array}{l}-0.001 \\
(0.003)\end{array}$ & $\begin{array}{l}-0.002 \\
(0.001)\end{array}$ \\
\hline After $2011 * \mathrm{I}(40<$ dist $<=50)$ & $\begin{array}{c}-0.072 * * * \\
(0.007)\end{array}$ & $\begin{array}{c}-0.071 * * * \\
(0.007)\end{array}$ & $\begin{array}{c}0.002 \\
(0.002)\end{array}$ & $\begin{array}{c}0.000 \\
(0.001)\end{array}$ \\
\hline After $2011 * \mathrm{I}(50<$ dist $<=75)$ & $\begin{array}{c}-0.024 * * * \\
(0.004)\end{array}$ & $\begin{array}{c}-0.031 * * * \\
(0.004)\end{array}$ & $\begin{array}{l}-0.002 \\
(0.002)\end{array}$ & $\begin{array}{c}-0.014 * * * \\
(0.001)\end{array}$ \\
\hline After $2011 * \mathrm{I}(0<$ dist $<=10) *$ License & & $\begin{array}{c}-0.052^{* * * *} \\
(0.018)\end{array}$ & & \\
\hline After $2011 * \mathrm{I}(10<$ dist $<=20) *$ License & & $\begin{array}{l}-0.089 \\
(0.058)\end{array}$ & & \\
\hline After $2011 * \mathrm{I}(20<$ dist $<=30) *$ License & & $\begin{array}{c}-0.051 * * * \\
(0.007)\end{array}$ & & \\
\hline After $2011 * \mathrm{I}(30<$ dist $<=40) *$ License & & $\begin{array}{l}0.032 * * \\
(0.013)\end{array}$ & & \\
\hline After $2011 * \mathrm{I}(40<$ dist $<=50) *$ License & & $\begin{array}{l}0.047^{* *} \\
(0.020)\end{array}$ & & \\
\hline After $2011 * \mathrm{I}(50<$ dist $<=75) *$ License & & $\begin{array}{c}0.034 * * * \\
(0.005)\end{array}$ & & \\
\hline Observations & 272,011 & 272,011 & $2,017,772$ & $2,079,534$ \\
\hline R-squared & 0.750 & 0.751 & 0.800 & 0.799 \\
\hline Geo and Region Controls & $\mathrm{Y}$ & $\mathrm{Y}$ & $\mathrm{Y}$ & $\mathrm{Y}$ \\
\hline Distance band-by-year Controls & $\mathrm{N}$ & $\mathrm{N}$ & $\mathrm{Y}$ & $\mathrm{Y}$ \\
\hline
\end{tabular}

Notes: The table reports results from fixed effects regressions of log price on an interaction between a time indicator which indicates the post-earthquake period (after 2011) and indicators for a distance rings from the earthquake location in Preese Hall 1 (columns 1 and 2) or placebo earthquake locations (column 3) and placebo well locations (column 4). Column 2 includes another set of interaction terms that distinguish within distance rings licensed from non-licensed areas. The omitted category is the $75-100 \mathrm{~km}$ bin. All regressions are conditional on quarter-by-year fixed effects, house controls, output area fixed effects geo-by-year controls, and region-by-year controls. Columns 3 and 4 include additional controls for distance ring-by-year interactions. Output areas in the top quartile of the population density distribution and minor and major urban centers are excluded from all specifications. The time horizon is Q1/2005Q2/2014. Round brackets report standard errors clustered on the output area level. ${ }^{* *} \mathrm{p}<0.01{ }^{* *} \mathrm{p}<0.05,{ }^{*} \mathrm{p}<0.10$ 
Table A4: Community Charter

\begin{tabular}{|c|c|c|c|c|}
\hline & $\begin{array}{l}\text { (1) } \\
\text { (A) }\end{array}$ & $\begin{array}{l}(2) \\
(\mathrm{B})\end{array}$ & $\begin{array}{l}\text { (3) } \\
\text { (C) }\end{array}$ & $\begin{array}{l}\text { (4) } \\
\text { (D) }\end{array}$ \\
\hline After $2008 *$ License Area & $\begin{array}{c}0.002 \\
(0.002)\end{array}$ & $\begin{array}{c}0.003 \\
(0.002)\end{array}$ & $\begin{array}{c}0.002 \\
(0.002)\end{array}$ & $\begin{array}{l}-0.000 \\
(0.002)\end{array}$ \\
\hline After $2011 *$ License Area & $\begin{array}{c}0.003 \\
(0.002)\end{array}$ & $\begin{array}{c}0.012 \text { *** } \\
(0.002)\end{array}$ & $\begin{array}{l}-0.000 \\
(0.002)\end{array}$ & $\begin{array}{c}0.008 * * * \\
(0.003)\end{array}$ \\
\hline After $2013 *$ License Area & $\begin{array}{c}0.003 \\
(0.002)\end{array}$ & $\begin{array}{c}0.007 * * * \\
(0.003)\end{array}$ & $\begin{array}{c}0.005 * * \\
(0.003)\end{array}$ & $\begin{array}{c}0.007 * * \\
(0.003)\end{array}$ \\
\hline After $2008 *$ License Area*Shale & $\begin{array}{l}-0.003 \\
(0.005)\end{array}$ & $\begin{array}{c}0.004 \\
(0.006)\end{array}$ & $\begin{array}{l}-0.003 \\
(0.006)\end{array}$ & $\begin{array}{l}-0.007 \\
(0.006)\end{array}$ \\
\hline After $2011 *$ License Area*Shale & $\begin{array}{c}0.002 \\
(0.006)\end{array}$ & $\begin{array}{c}0.004 \\
(0.006)\end{array}$ & $\begin{array}{l}-0.002 \\
(0.006)\end{array}$ & $\begin{array}{l}-0.005 \\
(0.007)\end{array}$ \\
\hline After $2013 *$ License Area*Shale & $\begin{array}{c}0.005 \\
(0.007)\end{array}$ & $\begin{array}{c}0.005 \\
(0.007)\end{array}$ & $\begin{array}{c}0.008 \\
(0.007)\end{array}$ & $\begin{array}{c}0.009 \\
(0.008)\end{array}$ \\
\hline After $2008 *$ License Area*Earthquake & $\begin{array}{l}-0.010 \\
(0.006)\end{array}$ & $\begin{array}{c}-0.031 * * * \\
(0.007)\end{array}$ & $\begin{array}{l}-0.004 \\
(0.007)\end{array}$ & $\begin{array}{l}-0.002 \\
(0.007)\end{array}$ \\
\hline After $2011 *$ License Area*Earthquake & $\begin{array}{c}-0.029 * * * \\
(0.007)\end{array}$ & $\begin{array}{c}-0.036 * * * \\
(0.008)\end{array}$ & $\begin{array}{c}-0.036^{* * *} \\
(0.008)\end{array}$ & $\begin{array}{c}-0.029 * * * \\
(0.008)\end{array}$ \\
\hline After $2013 *$ License Area*Earthquake & $\begin{array}{c}-0.027 * * * \\
(0.009)\end{array}$ & $\begin{array}{c}-0.028 * * * \\
(0.009)\end{array}$ & $\begin{array}{c}-0.036 * * * \\
(0.009)\end{array}$ & $\begin{array}{c}-0.034 * * * \\
(0.009)\end{array}$ \\
\hline Observations & $1,187,630$ & 756,248 & 517,580 & 513,063 \\
\hline R-squared & 0.817 & 0.802 & 0.828 & 0.821 \\
\hline Geo and Region Controls & Y & $\mathrm{Y}$ & Y & $\mathrm{Y}$ \\
\hline
\end{tabular}

Notes: The table reports results from fixed effects regressions of log price on an interaction between a time indicator which either indicates the post-license period (after 2008), the post-earthquake period (after 2011), or the postcommunity charter period (after 2013) and an indicator for (i) licensed areas, (ii) areas licensed for shale gas exploration, or (iii) areas licensed for shale gas exploration where the earthquake happened. All regressions are conditional on quarter-by-year fixed effects, house controls, output area fixed effects geo-by-year controls, and region-by-year controls. Panel A uses all Output Areas within a buffer of $20 \mathrm{~km}$ around the licensed areas as control group. Panel B uses the 14th licensing round areas but exclude the $20 \mathrm{~km}$ buffer around the licensing area. Sample (C) uses all Output Areas that were licensed under previous rounds as control group. Sample (D) restricts the sample to all Output Areas which the British Geological Survey classifies as promising for shale gas development. Output areas in the top quartile of the population density distribution and minor and major urban centers are excluded from all specifications. The time horizon is Q1/2005-Q2/2014. Round brackets report standard errors clustered on the output area level. ${ }^{* * *} \mathrm{p}<0.01,{ }^{* *}$ $\mathrm{p}<0.05,{ }^{*} \mathrm{p}<0.10$ 